\title{
Half a Century of Hawaiian Marine Natural Products*
}

Authors

Affiliations
Kehau A. Hagiwara ${ }^{1}$, Anthony D. Wright ${ }^{1,2}$

${ }^{1}$ DKI-College of Pharmacy, University of Hawaii at Hilo, Hilo, Hawaii, USA

2 Right Consulting, Hilo, Hawaii, USA

Key words
Hawaii
marine
natural products
algae
sponges
cyanobacteria
bacteria
fungi

received Sep. 16, 2015

revised February 24, 2016

accepted March 19, 2016

Bibliography

DOI http://dx.doi.org/

$10.1055 / \mathrm{s}-0042-105876$

Published online May 9, 2016

Planta Med 2016; 82: 800-815

(c) Georg Thieme Verlag KG

Stuttgart · New York .

ISSN 0032-0943

Correspondence

Anthony D. Wright

Right Consulting

15 Amauulu Road

Hilo, Hawaii 96720

USA

adwhawaii@gmail.com

\section{Abstract}

The following review covers the primary literature concerning marine natural products isolated for the first time from organisms collected around the islands of Hawaii published in the 51-year period 1964 to July 2015. The review is divided into seven main sections based on major taxonomic groupings; algae, sponges, mollusks, miscellaneous invertebrates, cyanobacteria, bacteria, and fungi. The aim of the review is to discuss the compounds and information concerning their original biological activity and other potentially interesting properties. The majority of the 320 structures of isolated compounds are not shown directly in

\section{Introduction}

$\nabla$

The Pacific islands, commonly referred to as the State of Hawaii, are regarded as the most geologically isolated pieces of land on our planet. The State is composed of eight main islands that cover 6423.4 miles $^{2}\left(16636.5 \mathrm{~km}^{2}\right)$ : Niihau, Kauai, Oahu, Molokai, Lanai, Maui, Kahoolawe, and Hawaii, often referred to as the "Big Island", and an upcoming island, the seamount named Loihi. All of the islands are volcanic in origin with the Big Island and Loihi still growing in area as a result of them being volcanically active. Due to their remote location and geological youth, their oceanbased biodiversity must be considered as depauperate, which is untypical of a tropical region. In general, moving down the island chain from Niihau to the Big Island reveals a marked decrease in ocean-based biodiversity especially for slowmoving and sessile life forms like nudibranchs,

\footnotetext{
* Dedicated to the pioneering marine natural products research into marine organisms of Hawaiian origin undertaken by the research groups led by Richard E. Moore and Paul J. Scheuer.
}

the review but are contained in the Supporting Information section in 22 figures, Figs. $1 \mathrm{~S}-22 \mathrm{~S}$. The Supporting Information section also contains Table $1 \mathrm{~S}$ that has information relating to the taxonomic identification of the source organism of each compound, collection location of the source organism, a trivial or semi-systematic name for each compound, as well as its general structural class. The authors hope that this review will be the spawning ground for other reviews and the basis for a great deal more research into the marine life found in Hawaiian waters.

Supporting information available online at http://www.thieme-connect.de/products

sea hares, algae, corals, sponges, tunicates and the like, and to some extent this is reflected in this review. The review itself covers the primary literature concerning marine natural products isolated from organisms collected around the islands of Hawaii published between 1964 and July 2015. In order to portray the chemical diversity of $\mathrm{Ha}$ waiian natural products, the structures shown are mainly for compounds first described from Hawaiian waters, and not of those previously reported from other locations. The bulk of the natural products discovered from the State of Hawaii were isolated from organisms collected from the waters around Oahu ( $\bullet$ Fig. 1).

Where applicable, the review also describes the isolated compounds in terms of their structures and activities as well as other relevant facts the reader may find useful. The review is organized into seven sections. The first four sections cover marine macro-organisms (algae, sponges, mollusks, and miscellaneous invertebrates), while the latter sections cover marine microbes (cyanobacteria, bacteria, and fungi). 0 Fig. 2 shows the number of compounds originally isolated from a Hawaiian source organism according to five-year 
periods after 1970 and the main taxonomic groupings (in the seven sections mentioned above) used in the review. At the end of the review, there is a Concluding Comments section that summarizes the highlights of the marine natural products research undertaken in the 51-year time period covered by the review as well as providing some suggestions and insights into the area in general.

\section{Algae \\ $\nabla$}

\section{Brown algae}

One of the earliest reported studies into marine natural products elaborated by Hawaiian organisms concerned algae and was conducted by the Moore group in 1968 [1]. In this paper, the authors reported the structure of an unstable dialkenylcyclopropane $C_{11}$ hydrocarbon, dictyopterene A (1 [๑ Fig. 3]), isolated from the brown algae Dictyopteris plagiogramma and Dictyopteris australis [1] from Waikiki, Oahu.

In 1970, a trialkenylcyclopropane named dictyopterene B (2) was isolated together with trans,cis,cis-1,3,5,8-undecatetraene (3) from the same algae by Pettus and Moore [2]. Further research into samples of these two algal species, D. plagiogramma and D. australis, by Pettus and Moore [3] yielded dictyopterenes $C^{\prime}$ and $D^{\prime}(4,5)$, the latter compound was shown to be identical with ectocarpene [4], trans,trans,cis-1,3,5,8-undecatetraene (6), trans,cis-undeca-1,3,5-triene (7), and trans,trans-undeca-1,3,5triene (8). In 1971, Roller et al. worked with a sample of D. plagiogramma, presumably also from Waikiki, Oahu, and found it to contain four new sulphur-containing lipids; S-(3-oxoundecyl) thioacetate (9), bis-(3-oxoundecyl) disulphide (10), 3-hexyl-4,5dithiacycloheptanone (11), and S-(trans-3-oxoundec-4-enyl) thioacetate (12) [5]. In 1971, Moore investigated two further samples of $D$. plagiogramma and $D$. australis, from unspecified locations, but presumably somewhere on Oahu, and isolated two bis-(3-oxoundecyl) polysulphides, bis-(3-oxoundecyl)trisulphide (13) and bis-(3-oxoundecyl)tetrasulphide (14), as low melting point crystalline solids [6]. When left to stand in methanol $\left(\mathrm{CH}_{3} \mathrm{OH}\right)$ for a prolonged period, the tetrasulphide (14) decomposed to yield the trisulphide (13) and elemental sulphur. From another investigation of $D$. plagiogramma and $D$. australis samples, again from an unspecified location in Hawaii, Moore and his colleagues identified a number of hydrocarbons and sulphur-containing compounds, two of which were new natural products $(15,16)$ [7]. In this report, it is suggested that both (-)-bis-(3-acetoxyundec-5-enyl) disulphide (15) and (-)-bis-(3acetoxyundec-5-enyl)thioacetate (16) are possible precursors of the aforementioned undeca-1,3,5-trienes [3]. Other new natural products reported from algae belonging to the genus Dictyopteris were the two cyclic ketones (+)-(R)-4-butylcyclohepta-2,6dienone (17 [๑ Fig.3]) and (+)-(R)-6-butylcyclohepta-2,4dienone (18 [๑ Fig. 3]) [8], both of which were noted for their strong odors. The absolute configurations of both molecules were determined by synthesis and CD spectral comparisons. Surprisingly, the optical rotation of $\mathbf{1 8}$ was reported as +1120 , while that for 17 was given as +96 . It seems likely that there might be a factor of 10 error in the value reported for 18 , with +112 being a more realistic value based on what is known about the molecular weights and absolute configurations of the two molecules. The final report concerning the natural products yielded by algae from the genus Dictyopteris found in Hawaii was published in 1974 and was a review summarizing the current knowledge about the

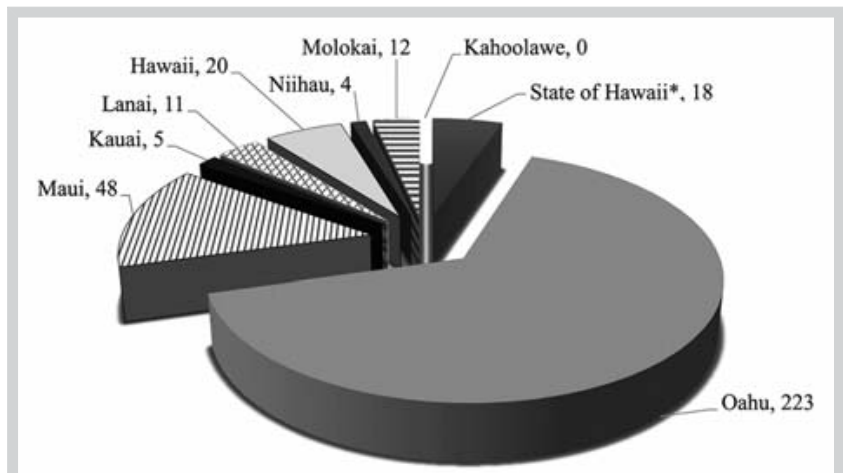

*Specific location not identified

Fig. 1 Number of compounds discovered from each of the Hawaiian Islands.

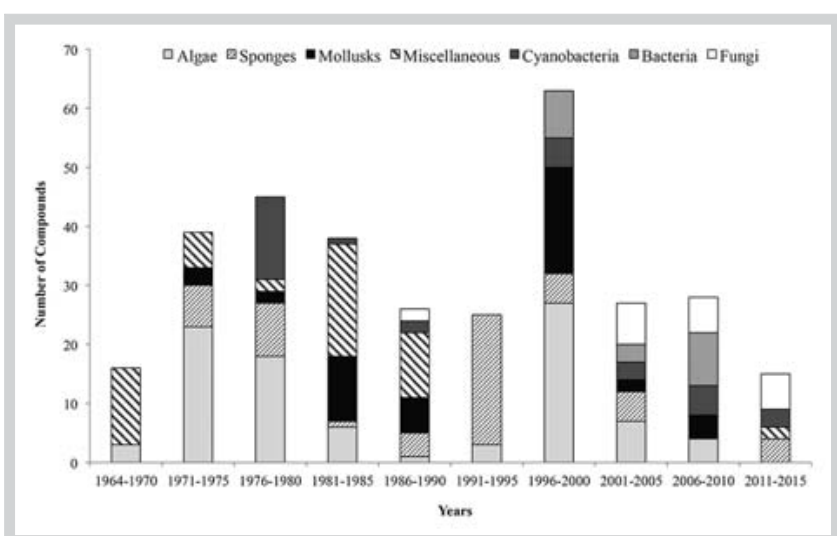

Fig. 2 Number of compounds originally isolated from the Hawaiian Islands according to five-year periods after 1970 and the main taxonomic groupings used throughout this review.

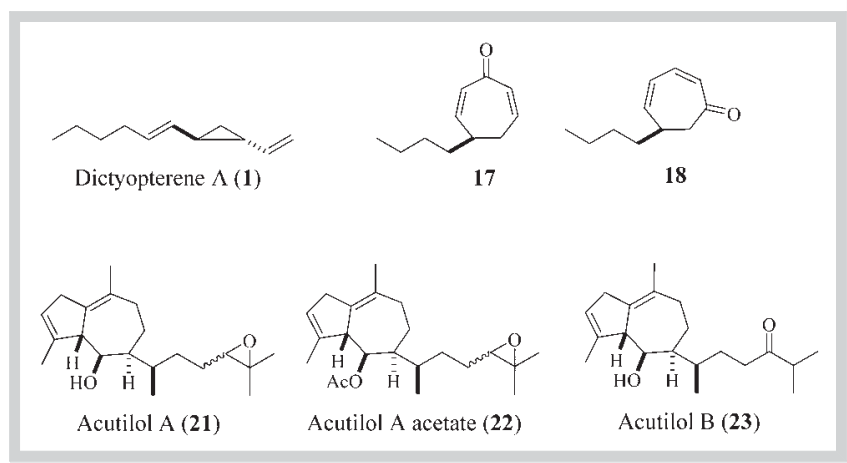

Fig. 3 Selected isolates from brown algae.

odoriferous $C_{11}$ hydrocarbon research undertaken by the Moore group since 1968 [9]. In terms of bio- and ecological activity, only the previously reported compound, ectocarpene (dictyopterene $\left.D^{\prime}, 5\right)$, is implicated by being the Cope rearrangement product of the sperm-attracting substance 1-((1E,3Z)-hexa-1,3-dien-1-yl)2-vinylcyclopropane. 
Species from the cosmopolitan algal genus Dictyota are relatively common to parts of Hawaii and have been the subject of several investigations. The first of these examined a sample of Dictyota acutiloba collected off Kahala and Ala Moana Reefs, Oahu [10]. Two diterpenes, new and unusual for their time, were isolated and characterized as dictyoxepin (19) and dictyolene (20). The absolute configuration of dictyoxepin was determined by single-crystal X-ray crystallographic analysis of its p-bromophenlyurethane derivative. Nineteen years later, the second investigation of this species employed a sample collected from Tunnels Beach, Kauai [11]. This study resulted in the isolation of three bicyclic diterpene metabolites, acutilol A (21 [ $\odot$ Fig. 3]), acutilol A

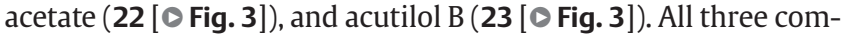
pounds were shown to be potent herbivore deterrents against both temperate and tropical fishes and sea urchins.

From a sample of Dictyota crenulata collected near Hauula Beach, Oahu, Finer et al. isolated and characterized dictyodial (24), employing both standard spectroscopic methods (NMR, IR, UV, MS), and by X-ray crystallographic analysis of the reduced form of this compound [12]. Dictyodial was found to have good antimicrobial properties but was not responsible for the observed antitumoral activity noted for the original algal extract. A winter collection of $D$. crenulata yielded $\beta$-crenulal (25) [13], which was shown to be identical to sanadaol isolated from a Japanese sample of the brown alga Pachydictyon coriaceum [14]. Two further diterpenes, $4 \beta$-hydroxydictyodial A and 18,0-dihydro- $4 \beta$-hydroxydictyodial $A(26,27)$, were isolated and characterized from $D$. crenulata collected near Kualoa Beach Park, Oahu, reported by Kirkup and Moore in 1983, and brings to an end the direct investigations of Dictyota species in Hawaii [15].

\section{Red algae}

As would be expected, specimens belonging to the red algal genus Laurencia, due to the prevalence of this algal genus worldwide, are the most studied of any Hawaiian algal genus. The $\mathrm{CH}_{3} \mathrm{OH}$ extract of Laurencia nidifica ("non-clumpy" variety) collected from Kahala Reef, Oahu, was found to have antimicrobial properties [16]. Fractionation of this material led to the isolation of a number of known metabolites and two new halogenated chamigrane derivatives, nidificene (28 [ $\odot$ Fig. 4]) and nidifidiene (29) [16]. The observed antimicrobial activity of the extract was attributed to the presence of the known compound laurinterol (30).

A third new chamigrane derivative was isolated from a "clumpy" variety of $L$. nidifica, also from Kahala Reef, Oahu, nidifidienol (31) [17]. The third investigation of $L$. nidifica, this time from Black Point Reef, Oahu, led to the isolation and characterization of two sesquiterpene alcohols, 3-methyl-5-(2,3,6-trimethylcyclohexa-2,5-dien-1-yl)pent-1-en-3-ol (32) and 3-methyl-5(2,3,6-trimethylphenyl)pent-1-en-3-ol (33) [18]. When allowed to stand for several days at $25^{\circ} \mathrm{C}, 32$ converts to the more stable 33. From the "non-clumpy" variety of L. nidifica, another chamigrane derivative was isolated, this time one that contained a third ring in the form of an ether (nidifocene, 34) [19]. Treatment of 34 with chromous sulphate cleanly removed the halogens to yield 35. From a green variety of $L$. nidifica, collected from the southern shores of Oahu, three new $\mathrm{C}_{15}$-halogenated non-terpenoid tricyclic ethers possessing a terminal ene-yne functionality, known as cis-maneonenes A and B $(36,37)$ and trans-maneonene B $(38)$, were isolated [20]. Continued investigation of the extract yielded a further three new metabolites, iso-maneonenes A and B (39, 40), and cis-maneonene $C$ (41) [21]. In this paper, the authors

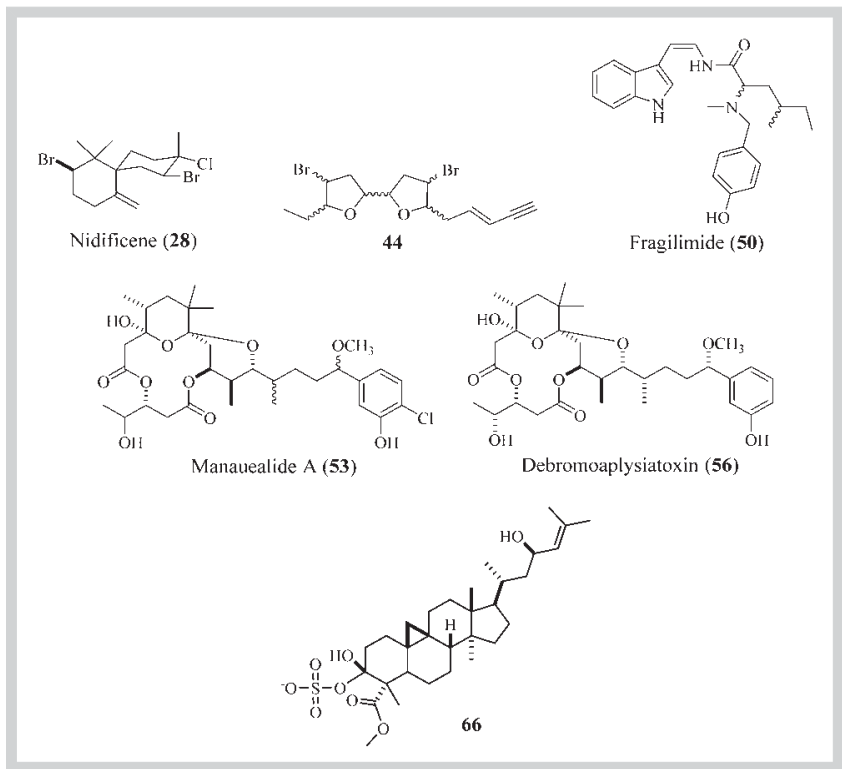

Fig. 4 Selected isolates from red algae.

note that the green variety of $L$. nidifica from which the latter compounds came, 39-41, may itself consist of several different varieties - chemotypes. Also from the green variety of $L$. nidifica, from an undefined collection site on Oahu, the unstable selinane derivative (+)-selin-4,7(11)-diene (42) was isolated and characterized [22]. The most recent report on $L$. nidifica (green variety) from Oahu summarized all of the authors' own work concerning the $\mathrm{C}_{15}$ non-terpenoid halogenated compounds discussed above [23], with the only new experimental data being the addition of $\mathrm{X}$-ray data for iso-maneonene B (40). Only one sample of L. nidifica from another Hawaiian island has been investigated. This sample came from near Port Allen, Kauai, and on workup yielded (+)-2(S)-N-acetamido-3(R)-acetoxyoctadecan-1-ol (43), a diacetate of dihydrosphingosine [24].

The lauroxane (44 [० Fig. 4]), at the time of its discovery from Laurencia majuscula, sampled from the north shore of Oahu, was the first example of a $\mathrm{C}_{15}$ compound containing a 2,2'-bistetrahydrofuran moiety [25]. Another sample of L. majuscula was collected on the north shore of Oahu near Kahuku, and found to contain kahukuenes A and B $(\mathbf{4 5}, 46)$, unprecedented diterpenes having a prenylated chamigrene structure as part of a decalin ring [26]. Clearly, these compounds are quite stable, as it seems the extract was not processed until many years after the alga was collected. The most recent report on algae from this genus comes from Laurencia cartilaginea, collected from Wai'anae, Oahu [27]. In this report, Juagdan and his colleagues describe the isolation and structure elucidation of two new halogenated sesquiterpenes, 8-bromo-9-hydroxychamigra-2(3),11(12)-dien-lone (ma'ilione) (47) and 2-chloro-1,8-dibromochamigr-11(12)en-9-ol (allo-isoobtusol) (48), together with four known halogenated sesquiterpenes, elatol, [1(15)Z,2Z,4R,8 S,9R]-8,15-dibromochamigra-l(15),2,11(12)-trien-9-o1, [1(15)E,22,4R,8 S,9R]8,15-dibromochamigra-1(15),2,11(12)-trien-9-ol, and iso-obtusadiene.

Asparagopsis taxiformis is an algal species traditionally consumed by Hawaiians known to contain a wealth of halogenated hydrocarbon-based metabolites [28-32]. The essential oil recovered from samples of A. taxiformis collected in Waikiki, Oahu, was ob- 
served to have bromoform as a major component, along with 17 other compounds including haloforms, carbon tetrabromide, tetrahalopropenes, polyhalo-but-4-en-2-ones, monohaloacetones, and 3,3-dihaloacroleins [28]. A second investigation of this alga focused on the volatile halogenated compounds found in its essential oil, collected from Waikiki, Oahu, between 1974 and 1975 [29]. This study resulted in the identification of 24 additional halogenated methanes, ethanes, ethanols, formaldehydes, acetaldehydes, acetones, 2-propanols, 2-acetoxypropanes, propenes, epoxypropanes, acroleins, and butenones. A sample collected from an unknown location in Hawaii, presumably somewhere on Oahu, was shown to contain five halogenated acetamides, seven halogenated but-3-en-2-ols, and 20 halogenated isopropanols [30]. In the report, there is no clear distinction between the new and known compounds. The last report by the same authors on the same algal species also provides no information on the site of collection, but again we assume it was somewhere on Oahu [31]. In this report, the authors investigated the aqueous extract of the alga and identified nine halogenated acetic acids, like $\mathrm{ClCH}_{2} \mathrm{COOH}$ and $\mathrm{BrCH}_{2} \mathrm{COOH}$, and nine halogenated acrylic acids, like $\mathrm{ClCH}=\mathrm{CHCOOH}$ and $\mathrm{BrCH}=\mathrm{CHCOOH}$. Unfortunately, the authors do not indicate which of their isolates are new and which are known.

Chemical investigation of Amansia glomerata from Black Point, Oahu, resulted in the isolation of a mixture of $\mathrm{N}$-acylsphingosines (49) that were identified via a series of chemical transformations and separations [24]. These compounds had not previously been found in algae.

The first basic indole alkaloids, fragilamide (50 [० Fig. 4]), and martensines A and B $(\mathbf{5 1}, \mathbf{5 2})$ to be isolated from a marine eukaryotic plant came from Martensia fragilis samples collected at both Black Point and Mokuleia, Oahu [33].

The known toxic alga, Gracilaria coronopifolia [34], collected from Waiehu, Maui, yielded the toxic compounds manauealides A-C (53-55 [๑ Fig. 4]) [35]. Manauealides A and C (53, 55) are new macrolides, whereas while manauealide B (54) was previously known as a semisynthetic derivative of debromoaplysiatoxin (56 [๑ Fig. 4]) [36]. A further investigation of another sample of G. coronopifolia from Maui enabled the absolute configuration of manauealide $\mathrm{C}(\mathbf{5 5})$ to be determined and also led to the isolation of anhydrodebromoaplysiatoxin (57) [37]. In several bioassays, 57 was shown to be inactive, however, low-dose injections into mice caused them to have diarrhea, thus revealing the potentially toxic nature of this and other related compounds. The most recent report on $G$. coronopifolia described the isolation and characterization of malyngamides $\mathrm{M}$ and $\mathrm{N}(\mathbf{5 8}, \mathbf{5 9})$ and malyngamide I acetate (60) from a sample also collected from Waiehu, Maui, one week after a food poisoning event [38]. The absolute configuration of $\mathbf{6 0}$ was deduced employing the reverse octant rule. As the type of compounds 58-60 represent are found almost exclusively from cyanobacteria, the authors' suggest that their collection may well have contained significant quantities of such a contaminant.

More recently, in 2013, molecular techniques were applied to the analysis of microbes associated with native and invasive Hawaiian macro-algae, including samples of $G$. coronopifolia (native), Gracilaria salicornia (invasive), and L. nidifica (native). The authors found the clone library derived from G. coronopifolia contained $28 \%$ cyanobacterial sequences, and G. salicornia and L. nidifica had cyanobacterial sequence frequencies of $71 \%$ and $8 \%$, respectively [39]. These findings may provide the basis for

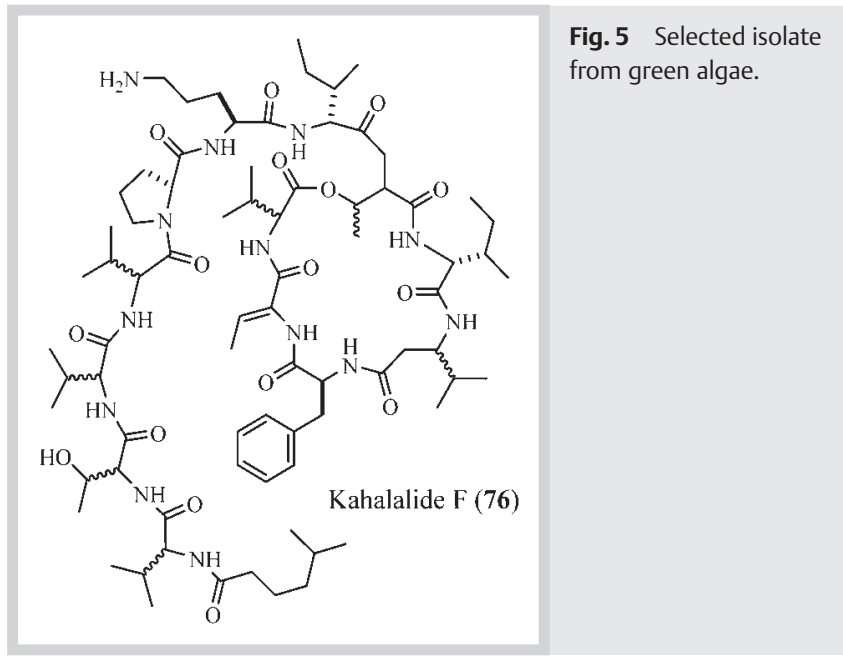

the identification of the proposed cyanobacterial origins of $G$. coronopifolia toxins $[34,35,37,38]$.

Investigations of Chondrococcus hornemanni, now known as Porteria hornemanni, from Hawaii started in the mid-seventies [40, 41]. The first of these describes the isolation, from two different samples, of (3S)-cis-octa-1,5-dien-3-ol (61), which is proposed to be a possible precursor of the sperm-attracting compound fucoserratene, known from the brown alga Fucus serratus [40]. The samples came from Black Point and Halona Blowhole, both on Oahu. The second report describes a number of linear and bicyclic halogenated monoterpenes, including chondrocoles A and B $(62,63)[41]$. These compounds also came from samples collected from Black Point and Halona Blowhole, which demonstrate through their chemical variation that they might belong to different chemotypes. In the third paper related to plants of the genus Porteria (= Chondrococcus), the authors corrected the structure of 62 to 64 based on an X-ray study of a related compound, chondrocolactone (65) [42], isolated from a sample from Halona Blowhole, Oahu.

The final red alga to be discussed here, Tricleocarpa fragilis, was collected off of Nanakuli Beach Park, Oahu [43]. After workup, the extract was fractionated to yield 10 new sulphated terpenoids, including six cycloartenol sulphates (66, 67-71 [॰ Fig.4]), two 29-nor-cycloartenol sulphates $(\mathbf{7 2}, \mathbf{7 3})$, and two 29-nor-

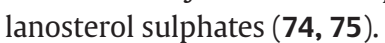

In the brine shrimp bioassay [43] some of the compounds demonstrated moderate to low activity $(66,68)$. In cell-based cytotoxicity assays, compounds 72-75 demonstrated moderate to low activity, but nothing at a level that would have led to their being further developed.

\section{Green algae}

There are only six reports of research being undertaken on green algae from Hawaii, all concerning Bryopsis spp., collected around Oahu. The first of these appeared in 1993 and described the depsipeptide kahalalide $F(76)$ isolated from both the sacoglossan mollusk Elysia rufescens and one of its dietary components, Bryopsis sp. [44]. Kahalalide F (76 [○ Fig. 5]), a depsipeptide, was shown to have a variety of biological activities, including selective antitumoral, antiviral, and antimicrobial, as well as being somewhat immunosuppressive, and was the only kahalalide to progress to any clinical trials, indeed the only one to have any significant activity in applied assays (see Concluding Comments). 


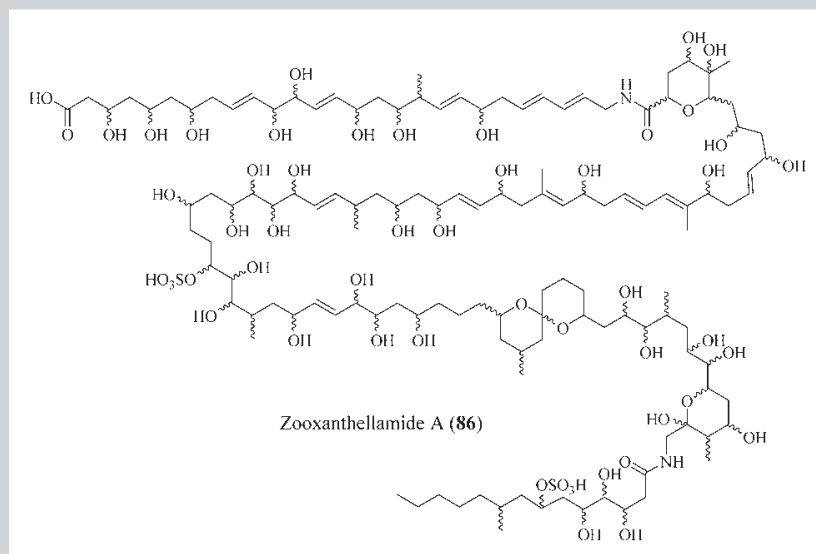

Fig. 6 Selected isolates from microalgae (protists).

The next report in 1996 also concerned E. rufescens and Bryopsis sp. samples [45]. This time a further six new depsipeptides were described of which three kahalalides, A, B, and G (77-79), were found to be in the alga. Of these, none were shown to have any biological activity. In 1999, a Japanese group reported the isolation of kahalalide $K(\mathbf{8 0})$, a cyclic depsipeptide with a new array of three L- and three D-amino acids. This compound was devoid of bioactivity in the applied assays [46]. Towards the end of the discussion in this paper the authors suggest the origin of the kahalalides is still unclear as their algal samples clearly contained cyanobacterial epiphytes that could be the source of such molecules. Horgen and colleagues described kahalalide $\mathrm{O}(\mathbf{8 1})$ initially from samples of Elysia ornata (Mollusk) from Point Black, Oahu, and later from Bryopsis sp., collected from the west coast of Oahu [47]. This cyclic depsipeptide was also found to be devoid of activity in the applied cytotoxicity studies. Kahalalides P and Q $(82,83)$, both cyclic depsipeptides containing a 3-hydroxy-9methyldecanoic acid residue, were isolated from a sample of Bryopsis sp., collected from Kewalo Basin, Oahu [48]. Like most of the other kahalalides discussed here, kahalalides P and Q (82, 83) were found to be inactive in the applied bioassays, including those related to cytotoxicity. The most recent report on Bryopsis spp. concerns samples of Bryopsis pennata collected from Kahala Bay, Oahu [49]. From $20 \mathrm{~kg}$ of material, the authors isolated two new cyclic-depsipeptides, 5-hydroxykahalalide $\mathrm{F}(\mathbf{8 4})$ and norkahalalide $A(85)$. In terms of biological activity, the authors suggest their research results and insights gained from testing their molecules might lead to new research with natural products aimed at the search for ligands selective for the $\mathrm{Y}_{1}$ receptor, a receptor implicated in a variety of psychiatric disorders.

\section{Microalgae (protista)}

Studies involving microalgae (protists) isolated from the ocean surrounding Hawaii focused on a culture of a free-swimming dinoflagellate, Symbiodinium sp. The source of the isolate was initially documented as sand collected from the beach of Coconut Island, Hawaii, in 1996 [50]. In two later reports by Onodera et al. the source was said to be a Hawaiian tide pool [51,52], and in a further report, from a Hawaiian sand beach [53]. From reading these papers it seems evident that Onodera and collaborators actually worked with a single strain of Symbiodinium sp., designated HA3-5, from which they isolated a series of polyhydroxylated diamides named zooxanthellamides A (86

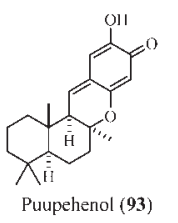

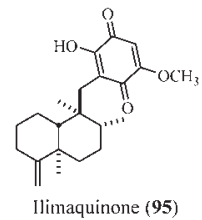<smiles>CC(=CCCc1ccoc1)CCCC(=O)NCCCOP(=O)(O)OCCCCC(C)C</smiles><smiles>C=CC(=CCCC(C)C1CCC2C3CC=C4CC(O)CCC4(C)C3CCC2(C)C1CCC(C)C(C)C)C(C)C</smiles>

I,ehualide B (114)
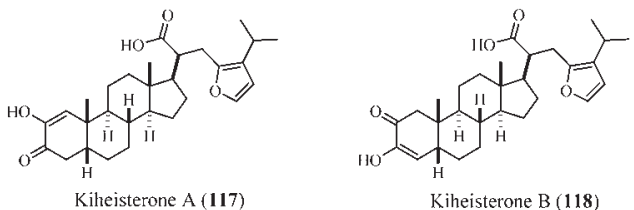<smiles>CC1=CC2(C(C)C)CCC(C(C)C)C(C)(C(C)(C)C)C2CC1</smiles><smiles>C=CC(C)(C)CCC=C(C)CCC=C(C)CCC=C(C)C</smiles><smiles>CC(C)C1CC2(C#N)CC3CC1CC2C3</smiles>

122

125

128

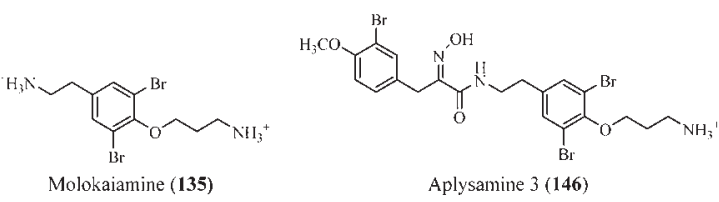

Fig. 7 Selected isolates from sponges.

[0 Fig. 6]), B (87), C-1 (88), C-2 (89), C-3 (90), C-4 (91), and C-5 (92) [51-53]. The $\mathrm{C}-1$ to $\mathrm{C}-5$ (88-92) compounds are macrocyclic lactones. Testing of $\mathbf{8 8 - 9 2}$ determined they had vasoconstrictive activity, with the lactones being significantly more active than their non-lactonized counterparts [53]. In more recent times, 2010, 2012 and 2014, extracts obtained from Hawaiian algae have been screened for their antioxidant activity and fucoxanthin and polyphenolics have been suggested as likely major contributing constituents responsible for the observed activity in some of the algae [54-56].

\section{Sponges \\ $\nabla$}

\section{Order Chondrosiida}

In 1979, sponge samples tentatively identified as Chondrosia chucalla, collected from Lanai, and the Blowhole, Oahu, were shown to contain puupehenone (93 [○ Fig. 7]) [57]. The final structure of this compound was deduced by X-ray analysis of its ozonolysis product (94).

\section{Order Dictyoceratida}

Ilimaquinone (95) was first isolated from Hippiospongia metachromia (now Dactylospongia metachromia), a bristly yellow orange or brown sponge found in the waters around Lanai, and near 
the Blowhole on the southeast coast and Shark's Cove on the north shore of Oahu [58]. The structure of $\mathbf{9 5}$ ( Fig. 7), finally resolved by X-ray analysis, is quite an unusual one being composed of a rearranged drimane sesquiterpene part linked to a pentasubstituted benzoquinone. Even though the original organic extract of this sample was shown to have antimicrobial activity, there appears to have been no further investigation of ilimaquinone's (95) potential as an antibiotic.

Puupehenol (96), a potent antioxidant antimicrobial meroterpenoid, was isolated from a Dactylospongia sp., collected from a depth of $130 \mathrm{~m}$ by a remotely operated vehicle (ROV) working in the Au'au channel between Maui and Hawaii [59]. From this same $\mathrm{CH}_{3} \mathrm{OH}$ extract, a methoxypuupehenol dimer was also isolated and characterized (97). In this paper, the authors also report finding puupehenone (93) and propose it as an artifact of isolation.

A Dysidea fragilis sponge, collected from Kaneohe Bay, Oahu, yielded upial (98), an unusual tricyclic non-isoprenoid sesquiterpene aldehyde [60]. The structure of upial was confirmed from the results of a lanthanide shift reagent study performed with upiol (99), the reduced form of 98. A second investigation of D. fragilis from Kaneohe Bay, Oahu, as well as of two of its known predators, the nudibranchs Hypselodoris godeffroyana and Chromodoris maridadilus, yielded two tricyclic furanosesquiterpenes, nakafuran-8 (100) and nakafuran-9 (101), with fish antifeedant properties [61].

Two sponge samples, Hyrtios spp., [62] one collected from the sandy bottom between Maui and Molokini carter $(-30 \mathrm{~m})$ and the other from submerged lava tubes on the north and west shores of Oahu $(-10 \mathrm{~m})$, were found to contain three new meroterpenoids (102-104) related to puupehenone (93). Compounds 102 (21-chloropuupehenol) and 103 (15-oxopuupehenol) were in both sponge samples while 104 (molokinenone - also chlorinated) was only noted in the sample from Maui. In bioassays, 102 was shown to have significant and selective antitumor and antimalarial activities. Poipuol (105), isolated from a Hyrtios sp., collected near Brenneke's Ledge, Kauai, in 2003, is an unusual small polyketide unique to the genus [63]. The structure of $\mathbf{1 0 5}$ suggests that it is more likely of microbial or cyanobacterial origin than being produced by the sponge itself. Cytotoxicity testing of $\mathbf{1 0 5}$ towards several cancer cell lines showed it to be inactive. The most recent investigation of a Hyrtios sp., collected in 2011 from a depth of $85 \mathrm{~m}$ in the Au'au channel between Maui and Lanai, led to the isolation of au'auamine (106) plus a peroxy dimer (107) [64], probably derived from 93 . The sponge was selected for investigation based on its $\mathrm{CH}_{3} \mathrm{OH}$ extract having antioxidant and antimicrobial properties. Bioassays performed with 106 showed it to have significant antioxidant activity and to be antibacterial. From the south shore of Maui at a depth of about $13 \mathrm{~m}$, a sample of Spongia oceania was collected. The ethanol (EtOH) extract of the dry sample yielded pokepola ester (108 [ $\bullet$ Fig. 7]), a diester of phosphoric acid of mixed biosynthetic origin, after repeated solvent partitioning, countercurrent chromatography, gel permeation chromatography (LH-20), and finally reversed-phase HPLC (RP-HPLC) [65]. The molecule, like many others from sponges, may be of microbial origin. In bioassays, 108 was shown to have mild HIV inhibitory activity.

\section{Order Haplosclerida}

Callyspongia diffusa, collected from Kaneohe Bay, Oahu [66], yielded 24-ethyl- $\Delta^{5,24(28), 28}$-cholestatrien-3 $\beta$-ol (109 [ $\bullet$ Fig. 7]) [67]. This was the first report of a naturally occurring steroidal allene.
Three new pregnanes (110-112) were isolated from a Petrosia sp., formerly Strongylophora sp., collected at Puako, west Hawaii [68]; all structural deductions were confirmed by X-ray. In cytotoxicity studies, $\mathbf{1 1 1}$ was found to be the most active compound with an MIC of $1 \mu \mathrm{g} / \mathrm{mL}$ towards KB cells and $5 \mu \mathrm{g} / \mathrm{mL}$ towards LoVo cells.

\section{Order Homosclerophorida}

Bioassay-guided fractionation (brine shrimp bioassay) of the extract obtained with $80 \%$ aqueous $\mathrm{CH}_{3} \mathrm{OH}$ of a Plakortis sp., a sponge collected between Lehua Rock and Niihau Island, led to the isolation of four new polyketide derived metabolites, lehualides A to D (113-116) [69]. Cytotoxicity screening of the isolates showed lehualide B (114 [๑ Fig. 7]) and lehualide D (116 [๑ Fig. 7]) to have activity towards ovarian and leukemia cancer cell lines.

\section{Order Poecilosclerida}

From a sponge only assigned to order the Poecilosclerida, collected near Maalaea Bay, Maui, two mildly cytotoxic steroids oxidized at C-21, kiheisterones A (117 [० Fig. 7]) and B (118 [॰ Fig. 7]), were isolated [70].

The first halo-steroids, in this instance chloro-steroids, kiheisterones C-E (119-121) were discovered from an undescribed species of Strongylacidon, collected from Maalaea Bay, Maui [71]. The authors report no biological activity testing of these unusual halosteroids.

\section{Order Suberitida}

From a Halichondria sp., a sample collected by trawling at a depth of $200 \mathrm{~m}$ north of Oahu, two of the first marine isocyanides were isolated, a bicyclic sesquiterpene (122 [० Fig. 7]) and a acyclic diterpene (125 [๑ Fig. 7]), together with their corresponding formamides $(123,126)$ and isothiocyanates $(124,127)[72-74]$.

Chemical investigation of a nudibranch, Phyllidia varicosa, led the authors to research samples of the off-white sponge Hymeniacidon sp., known to be part of the animal's diet, collected from the Pupukea Coast, Oahu. From the EtOH extract of the sponge, the authors isolated 9-isocyanopupukeanane (128 [๑ Fig. 7]) and confirmed its structure by X-ray analysis of its phenylthiourea derivative [75].

The sterol composition of the sponge Terpios zeteki (now Suberites aurantiacus) collected from Kaneohe bay, Oahu, was described by Delseth and collaborators in 1979 [76], and included the structure of a new $\mathrm{C}_{26}$ sterol, $5 \alpha$-24-norcholestan-3 $\beta$-ol (129).

There are two reports on sponges from the genus Ciocalypta present in Hawaiian waters. The first of these described a specimen collected from Pupukea, Oahu, and reported the isolation of three nitrogen containing bisabolene sesquiterpenes, 7isocyanato-7,8-dihydro- $\alpha$-bisabolene (130), 7-[(p-bromobenzyl) ureido]-7,8-dihydro- $\alpha$-bisabolene (131), and 7-amino-7,8dihydro- $\alpha$-bisalbone chloride (132) [77]. The structure of 132 was confirmed by X-ray analysis of its $p$-bromobenzyl urea derivative. The second report, this time concerning a sponge from Ala Moana Reef on the west shore of Oahu, discussed a tricyclic sesquiterpene, isocyanoneopupukeanane (133) [78]. The structure solution of this rigid cage-like compound took advantage of several diagnostic 2D-NMR C-H long-range correlations (COLOC). 


\section{Order Verongida}

Other common genera researched from Hawaiian waters are those belonging to the order Verongida. The first isolate from a sponge belonging to this order, with a tentative taxonomic assignment, was 15-cyanopuupehenol (134) [79]. The sample was collected from waters off the south shore of Molokai. Interestingly, the authors make no speculation that this molecule might have been a possible precursor of puupehenone (93). Other specimens of this order collected from Maui and several beaches on Oahu, identified as belonging to either the genus Psammaplysilla or Pseudoceratina, have yielded a variety of different compounds. Moloka'iamine (135 [ $\odot$ Fig. 7]), a bromotyramine derivative, and five puupehenone-related compounds (136-140) were isolated from a sample belonging to an undescribed genus closely comparable to Psammaplysilla purpurea.

The samples were collected from a pier in Kaunakakai Harbour, Molokai, several locations along the south shore of Oahu, and waters south of Maui, and their extracts demonstrated activity towards KB cancer cells [80]. The authors report that all isolates exhibit a variety of biological activities, including cytotoxicity, antiviral, antifungal, and immunomodulatory activities. Reexamination of the sample previously discussed collected on the Wai'anae coast, Oahu, yielded moloka'iamine (135), and the new compounds $N$-methylceratinamine (141), two moloka'iamine derivatives, wai'anaeamines $A(142)$ and $B$ (143), together with psammaplysin A (144) [81]. Examination of the ethyl acetate (EtOAc) fraction obtained from the original extract after flash chromatography of the same sponge samples yielded bromotyramine derivatives named mololipids (145) for which there is no complete physical or spectroscopic information [82]. In the paper, the authors provide very general GC-MS data and spectroscopic data of lipid mixtures. Bioassays performed with the lipid mixtures showed them to have some selective activity towards the HIV-1 virus $\left(\mathrm{EC}_{50}\right.$ of $\left.52.2 \mu \mathrm{M}\right)$. The $\mathrm{EC}_{50}$ reported is clearly anomalous, as tests were undertaken with mixtures of lipids of varying molecular weights.

A sample positively identified as $P$. purpurea collected from a depth of $40 \mathrm{~m}$ off south Kihei, Maui, furnished three bromotyrosine derivatives, aplysamines 3-5 (146-148 [0 Fig. 7]) [83]. All compounds demonstrated moderate to weak nonselective cytotoxicity towards four cancer cell lines (KB, P388, A549, and HT29), were mildly antibacterial towards various gram-positive bacteria, and were inactive towards the HIV-1 virus.

\section{Mollusks}

\section{Sea hares}

The early 1970s saw the first reports on sea hares. Stylocheilus longicauda, collected in Kaneohe Bay, Oahu, yielded two toxins, aplysiatoxin (149) and debromoaplysiatoxin (56), as well as their nontoxic monoacetates $(\mathbf{1 5 0}, \mathbf{1 5 1})[36,84]$, together with stylocheilamide (152) [85]. From the same source organism, the new compounds makalika ester (153), makalikone ester (154 [๑ Fig. 8]), malyngamide $O(\mathbf{1 5 5})$, and malyngamide $P(\mathbf{1 5 6})$ were isolated from animals collected from Black Point, Oahu $[86,87]$. The paper concerning two proline esters $(153,154)$ was also the first report of a naturally occurring lyngbyatoxin A acetate (158) [86].

Malikone ester (154) and lyngbyatoxin A acetate (157 [० Fig. 8]) were determined to have moderate $\left(\mathrm{IC}_{50} \mathrm{~S}\right.$ of $2.5-5 \mu \mathrm{g} / \mathrm{mL}$ ) and potent $\left(\mathrm{IC}_{50}\right.$ of $0.05 \mu \mathrm{g} / \mathrm{mL}$ ) activities, respectively, against mouse
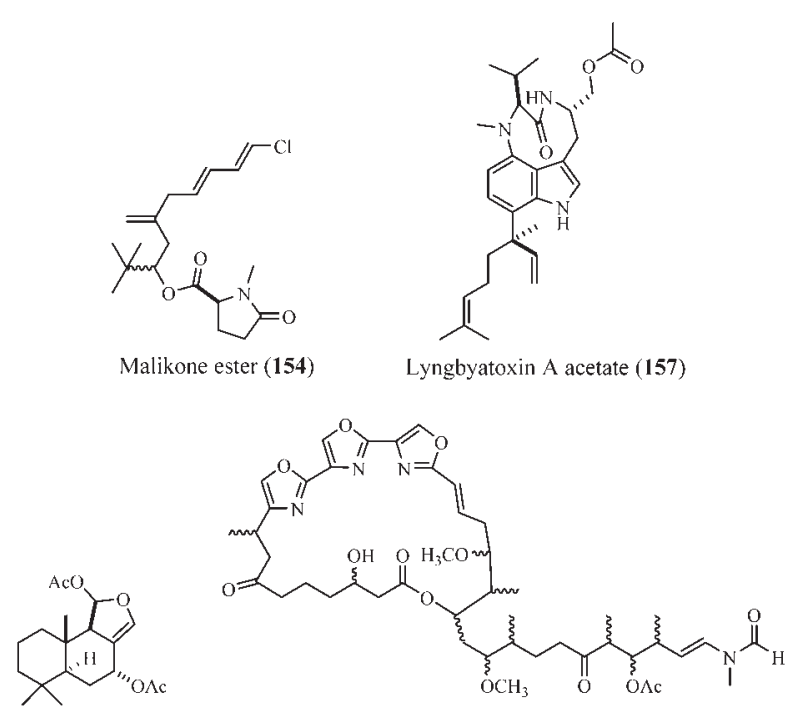

Olepupuane (164)

Ulapualide A (170)

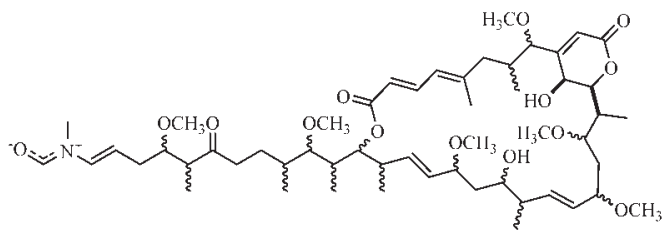

Sphinxolide (172)
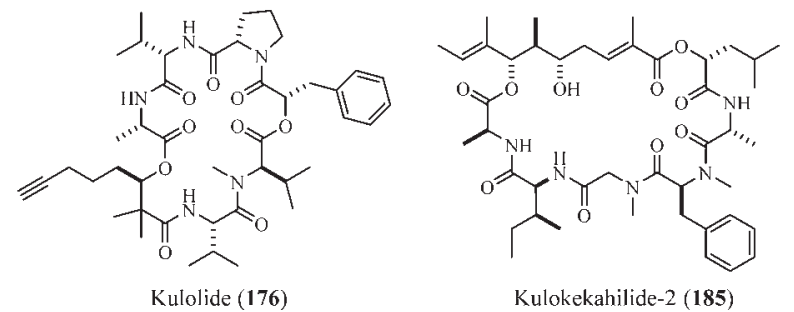

Kulokekahilide-2 (185)

Fig. 8 Selected isolates from mollusks.

lymphoma (P-388) cells, human lung carcinoma (A-549) cells, and human colon carcinoma (HTB 38) cells. Malyngamide O (155) showed moderate anticancer activity against mouse lymphoma (P388) cells, human lung carcinoma (A-549) cells, and human colon carcinoma (HT-29) cells.

The lipid extract of a collection of sea hares, Aplysia oculifera, from the Pupukea Coast, Oahu, where they were observed feeding on an unidentified species of the red alga Laurencia sp., was found to contain two bicyclic di-bromo di-ether $C_{15}$ enynes, E-ocellenyne (158) and Z-ocellenyne (159) [88]. It is likely that both of the compounds play a role in the defense of the collected animals, but clearly not against humans!

\section{Nudibranchs}

From the nudibranch Phyllidia varicosa, collected from the Pupukea Coast, Oahu, 9-isocyanopupukeanane (128) was isolated [75]. The same compound was also isolated from the EtOH extract of a sponge identified as Hymeniacidon sp., which was collected and extracted specifically to provide a sufficient quantity of compound to enable its complete characterization [75]. Four years later, the 2-isomer, 2-isocyanopupukeanane (160), was isolated 
and identified [89]. The final structure solution, including absolute configuration, was achieved through X-ray analysis.

The previously discussed compounds, nakafuran-8 (98) and nakafuran-9 (99), were isolated from two different mollusks, Chromodoris maridadilus and Hypselodoris godeffroyana, collected in Kaneohe Bay, Oahu. Both organisms had been observed feeding on the marine sponge Dysidea fragilis, suggesting a dietary source [60]. A separate study of the Pupukea Coast, Oahu, inhabitant Chromodoris youngbleuthi yielded three deacetylscalaradials, only one of which was found in its prey (161), the sponge Spongia oceania [90], and two of which were new natural products $(162,163)$.

Assessment of the sesquiterpene contents of eight porostome nudibranchs, two species from Hawaii collected at Ala Moana Reef, Fort Kamehameha, and the Pupukea Coast, belonging to the genus Dendrodoris, Dendrodoris nigra and Dendrodoris tuberculosa, found them to contain two new compounds, olepupuane (164 [० Fig. 8]) and its methoxy acetal (165) [91]. Olepupuane (164) was shown to have antifeedant properties toward the Pacific damsel fish (Dascyllus aruanus), with an $\mathrm{ED}_{50}$ of $15-20 \mu \mathrm{g} / \mathrm{mg}$ of food pellet.

The ilikonapyrone esters (167-169), all based on the bispyrone alcohol ilikonapyrone (166), were isolated from the nudibranch Onchidium verruculatum, collected from Portlock, Oahu [92]. These compounds have purported roles as defense allomones for this mollusk.

An analysis of the carbon tetrachloride $\left(\mathrm{CCl}_{4}\right)$ partition of the $\mathrm{CH}_{3} \mathrm{OH}$ extract of eggs of the mollusk Hexabranchus sanguineus collected at Pupukea, Oahu, yielded two antitumor macrolides, both 28-membered lactones with three contiguous oxazole rings, ulapualides A (170 [○ Fig. 8]) and B (171) [93]. Both compounds inhibited leukemia (L1210) cell proliferation $\left(\mathrm{IC}_{50} \mathrm{~S}\right.$ of $0.01-$ $0.03 \mu \mathrm{g} / \mathrm{mL}$ ) and the growth of Candida albicans [93], and are reported to be present in the adults, but in low concentrations.

Sphinxolide (172 [0 Fig. 8]) is a 26-membered macrolide isolated from an unidentified nudibranch found trapped in fishing nets off Oahu [94]. The compound was found to have potent activity against $\mathrm{KB}$ cells ( $\mathrm{IC}_{50}$ of $35 \mathrm{pg} / \mathrm{mL}$ ).

With seven publications and twelve compounds, Philinopsis speciosa is one of the most investigated and productive mollusks so far researched in the Hawaiian Islands. Specimens of P. speciosa collected from sandy tide pools at Pupukea, Oahu, led to two reports. The first of these described pulo'upone (173), a $\mathrm{C}_{16^{-}}$ alkadienone-substituted 2-pyridine [95]. The second publication describes two new polypropionates named niuhinone A and B $(174,175)$ [96]. A larger re-collection of this organism at Shark's Cove, Pupukea, Oahu, in 1994 yielded the depsipeptide kulolide (176 [O Fig. 8]), which exhibited significant biological activity against leukemia cells (L-1210) and murine leukemia cells (P388) with $\mathrm{IC}_{50}$ values of 0.7 and $2.1 \mu \mathrm{g} / \mathrm{mL}$, respectively [97]. Lethality of $\mathbf{1 7 6}$ to brine shrimp was not observed at $1.0 \mathrm{ppm}$. Furthermore, 176 caused a change in rat 3Y1 fibroblast cell morphology at $50 \mu \mathrm{M}$. From the same collection, the isolation and characterization of a linear tetrapeptide, pupukeamide (177), was also described [98]. The compound showed no cytotoxicity against murine leukemia (P388) cells. The authors use the presence of pupukeamide (177) to propose an ecological link via bioaccumulation through three trophic levels, Lyngbya spp. to Stylocheilus longicaudus to Philinopsis speciosa. The next report concerning the collection from Shark's Cove in 1994 yielded five new depsipeptides, kulolide-2 (178), kulolide-3 (179), kulokainalide-1 (180), kulomo'opunalide-1 (181), kulomo'opunalide-2
(182), and the unprecedented macrolide, tolytoxin-23-acetate (183) [99]. Kulokekahilide-1 and $-2(\mathbf{1 8 4}, \mathbf{1 8 5})$ represent the most recent depsipeptides isolated from $P$. speciosa samples $[100,101]$. Kulokekahilide-2 (185 [0 Fig. 8]) exhibited potent cytotoxicity towards P388, SK-OV-3, MDA-MB-435, and A-10 cells, with 184 being found to be significantly less active.

One of the more successful natural product stories from Hawaii concerns the genus Elysia. Investigations of this genus and its food source, Bryopsis sp., revealed the group of depsipeptides called the kahalalides. The first report involved both E. rufescens and Bryopsis sp., and yielded the aforementioned kahalalide $\mathrm{F}$ (76) [44]. Kahalalides A-E $(\mathbf{7 7}, \mathbf{7 8}, \mathbf{1 8 6}, \mathbf{1 8 7}, \mathbf{1 8 8})$ were also reported from a collection of this mollusk [45]. Both collections of the organism occurred at Black Point during 1991. The acyclic octa- and nona-peptides kahalalide $\mathrm{H}$ (189) and kahalalide J (190) were also isolated from E. rufescens and, in common with other acyclic peptides, they are reported to lack significant cytotoxicity [102]. The most recent report of kahalalides from Hawaiian $E$. rufescens specimens details the isolation of four further kahalalides, kahalalides V-Y (191-194) from two collections made in Kahala Bay, Oahu, during the time period 2003-2004 [103]. Surprisingly, none of these new metabolites demonstrates any activity approaching that documented for $\mathbf{7 6}$.

Although there are eight reported species of Elysia in Hawaii, only one other species has been studied for its secondary metabolite production/sequestration, E. ornata. This sample was collected from Black Point, Oahu, in 1997, and afforded the biologically inactive kahalalide $\mathrm{O}(\mathbf{8 1})$ [47].

\section{Miscellaneous Invertebrates}

$\nabla$

\section{Cnidarians}

One of the more infamous compounds to be discovered in Hawaii is the marine toxin known as palytoxin (PLTX) (195 [० Fig. 9]). Native Hawaiians previously collected a "seaweed" from a tide pool in Muolea, Hana, Maui, and used it to tip their spear points with a preparation that contained palytoxin to make "strikes" more likely to be fatal. It was later discovered that this "seaweed" was actually a species of zoanthid called Palythoa toxica. Chemical investigations of $P$. toxica, collected specifically from Muolea, resulted in Moore and Scheuer's first report in 1971 on the isolation of PLTX (195) [104]. It took another 10 years before the planar structure of PLTX was reported [105], and an additional year before the structure with its absolute configuration became available [106]. Palytoxin (195) has a molecular weight of approximately $3300 \mathrm{amu}$ and is toxic to mice at $0.15 \mu \mathrm{g} / \mathrm{kg}$ [104], it also possesses potent anticancer activity [107]. Reinvestigations of Palythoa tuberculosa and P. toxica collected from the same location on Maui yielded two 42-hydroxypalytoxin stereoisomers $(196,197)[108]$. These compounds exhibited different activities. P. tuberculosa afforded the $42 S$-hydroxy-50S-palytoxin (196) that is cytotoxic to HaCaT keratinocytes $\left(\mathrm{EC}_{50}\right.$ of $\left.9.3 \times 10^{-10} \mathrm{M}\right)$. The 42S-hydroxy-50R-palytoxin (197), isolated from $P$. toxica, had an $\mathrm{EC}_{50}$ of $1.0 \times 10^{-10} \mathrm{M}$ in the same assay. Comparatively, these stereoisomers are at least one order of magnitude less cytotoxic than PLTX ( $\mathrm{EC}_{50}$ of $\left.2.7 \times 10^{-11} \mathrm{M}\right)$ [108].

The soft coral Sinularia abrupta collected near the Blowhole on the southeast coast of Oahu, yielded pukalide [0 Fig. 9 (198)], a highly functionalized furanocembranolide [109], now known to have a significant ecological function in the life cycle of soft corals [110]. 
Collection of the endemic blue octocoral Anthelia edmondsoni (now Sarcothelia edmondsoni) collected from the north shore of Oahu, near Waimea Bay, lead to the isolation of the highly oxygenated xenicin diterpenoids waixenicin A and B $(\mathbf{1 9 9}, 200)$ [111].

Punaglandins (201-204), a series of eicosanoids containing an unprecedented C-10 chloro-function, were isolated from the octocoral Telesto riisei collected at various sites along the coast of Oahu [112]. The octocoral is quite unusual in the respect that is lacks symbiotic algae. The report mentions no biological activity for this interesting class of molecule.

Investigations of a deep-sea coelenterate used in the jewelry making industry, Gerardia sp., or gold coral, stemmed from a collection made employing a minisubmarine working at a depth of $350 \mathrm{~m}$. Initially referred to as Parazoanthus sp., the animal was later correctly identified as Gerardia sp., [113]. Interest in this organism was sparked by complaints of skin and mucous membrane reactions from the handling of freshly harvested coral. Unfortunately, no suitable laboratory bioassay was found to facilitate the hunt for the causative agent, but the brilliant fluorescence of the extract prompted the group to identify the responsible metabolites [113]. An EtOH extract made from the animals was found to be highly fluorescent [114]. Fractionation of this extract yielded 2-amino-3,9-dimethyl-5-dimethylamino-3 $\mathrm{H}$ 1,3,4,6-tetrazacyclopent[e]azulene monohydrate (205), a zoanthaxanthin whose structure was solved employing X-ray crystallography [114]. Later in 1978, Schwartz et al. reported the isolation of two new fluorescent nitrogenous pigments. From the acidified aqueous fraction of the $\mathrm{EtOH}$ extract of the animal [॰ Fig. 9], 205 and 2-amino-3,9-dimethyl-5-methylamino-3 $\mathrm{H}$ 1,3,4,6-tetrazacyclopent[e]azulene (206 [० Fig. 9]) were isolated [113]. In response to the longstanding debate of the biosynthetic origin of organic molecules in marine coelenterates (soft corals) between the animals themselves or the symbiotic zooxanthellae they harbor, the authors concluded that the pigments recovered from these animals must be synthesized by the animals because of their depth of habitation $(-350 \mathrm{~m})$, where photosynthesis is most unlikely to occur.

Another commercially valuable coral, Corallium sp., or Hawaiian pink coral, was harvested from depths of 300-350 m from the Moloka'i Channel off Makapu'u, Oahu. After harvesting, polyps were scraped off of the animals' endoskeleton and soaked in $\mathrm{CH}_{3} \mathrm{OH}$. Fractionation of the resultant extract led to the isolation of five diterpenes structurally related to xenicins, coraxenolide A, $B, C$, and D (207-210), and corabohcin (211) [115]. The structures of all isolates were resolved from the X-ray crystal structure determined for coraxenolide A (207).

Investigations of a collection of six other deep-sea (-360 m) gorgonians from waters off Makapu'u, Oahu, lead to the isolation of papakusterol (212) from all samples and 7-dehydropapakusterol (213) from only one sample, Acanthagorgia sp. Identifications of the organisms was pending at the time of publication, with only Acanthagorgia sp. being identified in the report [116].

A gorgonian from the family Paramuriceidae collected off Oahu at depths around $350 \mathrm{~m}$ yielded the new natural products 3-chloro7-isopropyl-1,4-dimethylazulene (214), 3-bromo-7-isopropyl1,4-dimethylazulene (215), and ehuazulene (216) [117]. The chloro- and bromo-isolates were previously known from synthesis [118]. A nitrogenous viscous blue oily azulene derivative, $N, N-$ dimethylamino-3-guaiazulenylmethane (217), was isolated from a different sample of the same species of organism, from the

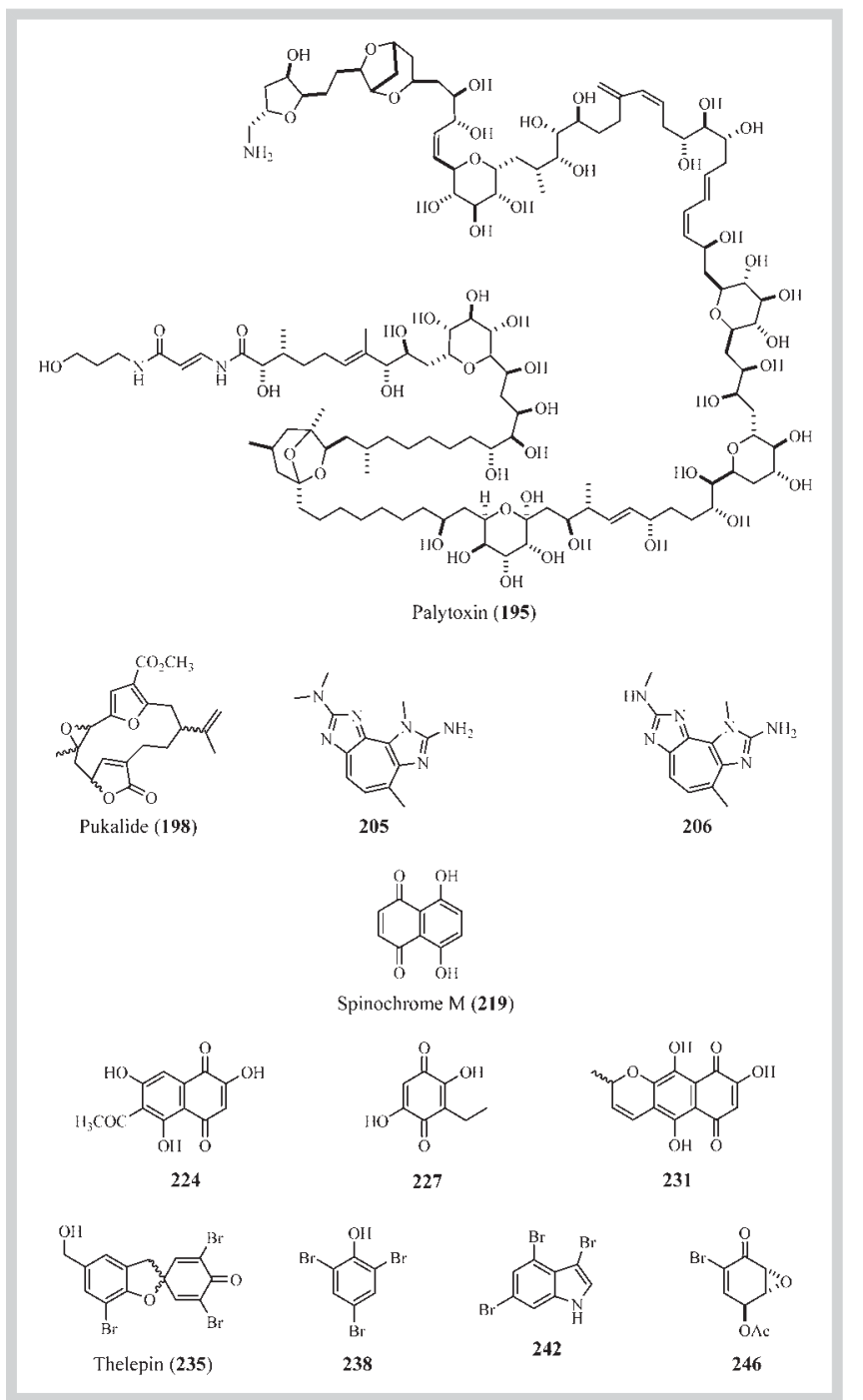

Fig. 9 Selected isolates from miscellaneous invertebrates.

same location, and from the same depth as the one just discussed [119].

Hexane extraction of a deep-sea example of the gorgonian Placogorgia sp., collected from a depth of $350 \mathrm{~m}$, yielded a tricyclic yellow crystalline guaianolide pigment that was fully conjugated and contained both keto and lactone functionalities (218) [120]. From the box jellyfish (Carybdea alata reclassified as Alatina alata), the 43-45 kDa protein toxins CaTX-A and B were isolated, and the cDNA and amino acid sequences for CaTX-A were also reported [121]. Hemolytic activity tests performed with sheep red blood cells showed 50\% hemolysis at concentrations of 70 and $80 \mathrm{ng} / \mathrm{mL}$ for the two compounds, respectively. A crayfish toxicity assay performed with Procambarus clarkii, using CaTX-A, showed it to have an $\mathrm{LD}_{50}$ of $5-25 \mathrm{mg} / \mathrm{kg}$.

\section{Echinoderms}

The earliest report concerning a marine natural product from Hawaiian waters concerned spinochrome M (219 [० Fig.9]), a polyhydroxylated naphthoquinone pigment, isolated from the spines of six species of Hawaiian sea urchins, Echinometra oblonga, Colobocentrotus atratus, Tripneustes gratilla, Echinithrix diadema, E. calamaris, and Diadema paucispinum [122]. This study 
was undertaken to establish whether the chemical diversity of naturally occurring spinochromes actually matched that reported in the literature. Interestingly, the authors' findings supported their suspicion that the literature contained a larger variety of spinchromes than actually occur in nature!

From the spines of two species of Echinithrix sea urchins, E. diadema and E. calamaris, collected from Kaneohe Bay, Oahu, 16 compounds, predominantly polyhydroxylated napthoquinones, were isolated, with the following 11 being new natural products: 2hydroxy-3-acetyl-naphthazarin (220), 2-hydroxy-6-ethyljuglone (221), 2-hydroxy-6-ethylnaphthazarin (222), naphthopurpurin (223), 2,7-dihydroxy-6-acetyljuglone (224 [๑ Fig.9]), 2,7-dihydroxy-3-ethylnaphthazarin (225), 2,7-dihydroxynaphthazarin (226), 2,5-dihydroxy-3-ethylbenzoquinone (227 [๑ Fig.9]) 2hydroxy-6-acetylnaphthazarin (228), 2,3,7-trihydroxy-6-acetyljuglone (229), and 2,3,7-trihydroxy-6-ethyljuglone (230) [123]. In 1968, the structure of the first pigment containing a four carbon unit attached to a naphthoquinone system was described; 2-methyl-8-hydroxy-2 H-pyrano[3,2-q]naphthazarin

(231 [॰ Fig. 9]) [124].

\section{Annelid}

The chloroform $\left(\mathrm{CHCl}_{3}\right)$ extract of the annelid Thelepus setosus collected in Kaneohe Bay, Oahu, was separated by preparative TLC and found to contain five new bromophenol-related metabolites (232-236; 235 [○ Fig. 9]) whose biological activities have yet to be reported [125].

\section{Acorn worms}

Investigations of a new species of acorn worm belonging to the genus Ptychodera, collected at a depth of $30 \mathrm{~m}$ from a cave at Kinau Point off the island of Maui, led to the isolation of 11 new brominated compounds (237, 238 [๑ Fig.9], 239-241, 242 [॰ Fig. 9], 243-245, 246 [॰ Fig. 9], 247) [126].

\section{Cyanobacteria \\ $\nabla$}

Lyngbya majuscula Gomont, now Moorea producens [127], is the most studied marine cyanobacterial species, probably due to its notoriety as the causative agent for outbreaks of contact dermatitis, more commonly referred to as "swimmers' itch," in Hawaii. The new genus name Moorea is an acknowledgement of the many years of work that Richard E. Moore and his group undertook with this marine cyanobacterium that is phylogenetically distinct from the freshwater Lyngbya, whose name is retained based on precedent. The main toxic component of $L$. majuscula (now M. producens), lyngbyatoxin A (248 [॰ Fig. 10]), was first isolated in 1971 from a Laie Bay collection on Oahu [128], but its structure was not resolved until eight years later [129]. Other investigations concerning subsequent collections of the Kahala Beach strain of L. majuscula (now M. producens) yielded 18 additional metabolites. Two major constituents of the lipophilic extract, the epimeric lipodipeptides majusculamide A and B (249, 250) [130], were the next two compounds to be described, followed by (+)- $\alpha(S)$-butyramido- $\gamma$-butyrolactone (251) [131], and then (-)-trans-7(S)-methoxytetradec-4-enoic acid (252) together with malyngamides $A$ (253) and B, the latter two compounds only being partially characterized [132]. The structure of malyngamide A (253) was eventually published in 1979 [133]. The next examination of the Kahala beach strain yielded malyngolide (254), which was found to have antibiotic activity against Myco-

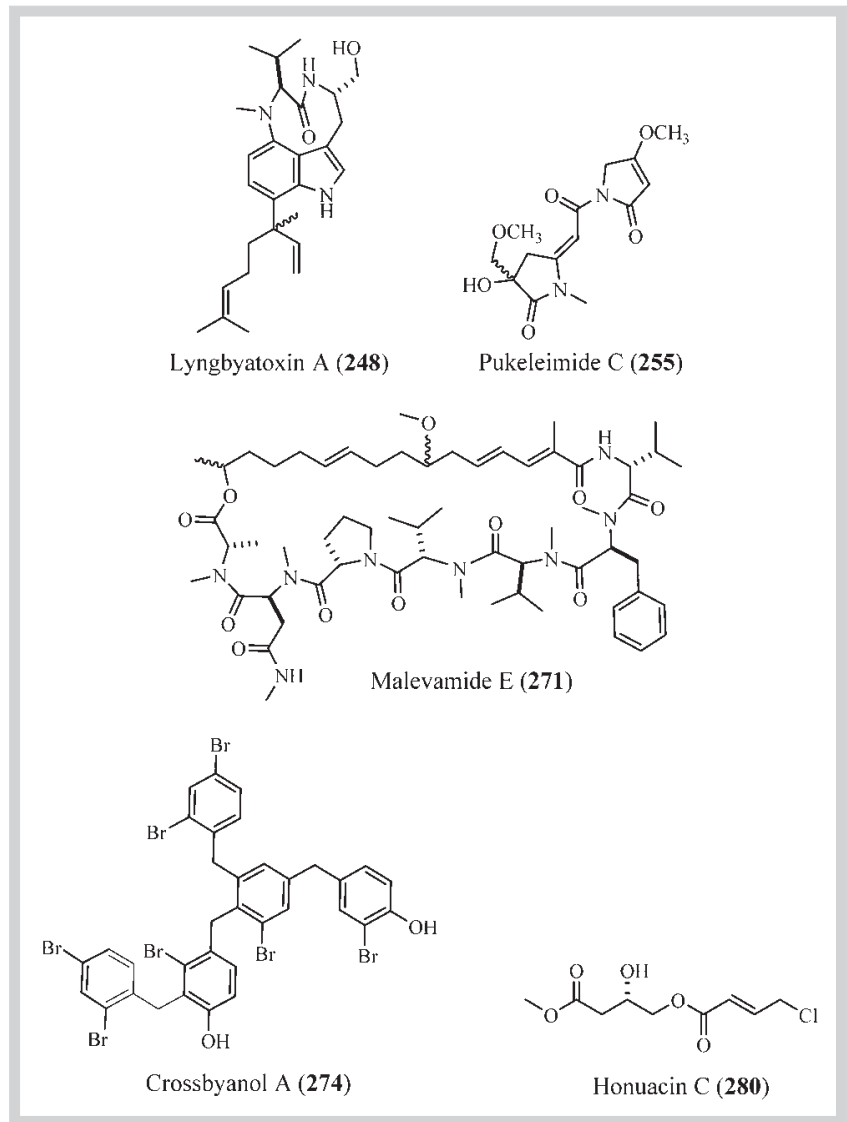

Fig. 10 Selected isolates from miscellaneous cyanobacteria.

bacterium smegmatis, Streptococcus pyrogenes, Staphylococcus aureus and Bacillus subtilis [134]. Following this report came the next class of compounds to come from $L$. majuscula, the pukeleimides, $1 \mathrm{H}$-pyrrol-2(5H)-one derivatives, pukeleimide C (255 [ $\odot$ Fig. 10]) being the first one to appear in the literature [135]. The structure of this compound was deduced by X-ray crystallographic examination. The authors also determined that their isolate exists as a racemic mixture having an optical rotation of 0 and no apparent $C D$ activity. From the same sample of L. majuscula that yielded pukeleimide C (255), pukeleimides A, $B$, and D-G (256-261) were also isolated and their structures proposed on the basis of spectroscopic data interpretation [136]. Lyngbyatoxins B and C $(\mathbf{2 6 2}, \mathbf{2 6 3})$, also from the Kahala beach strain of L. majuscula, were identified as irritants via a mouse ear irritant test [137]. The final report on L. majuscula compounds described isomalyngamides A and B (264, 265), which were shown to have lethal toxicity towards the crayfish Procambarus clarkii (250 and $500 \mu \mathrm{g} / \mathrm{kg}$, respectively) [138].

From the dichloromethane $\left(\mathrm{CH}_{2} \mathrm{Cl}_{2}\right)$-soluble part of a $70 \% \mathrm{EtOH}$ extract made from a sample of $L$. aestuarii Liebmann ex Gomont collected at Kamalo Jetty on Molokai, 2,5-dimethyldodecanoic acid (266) was reported and found to have pH-dependent herbicidal activity at concentrations above $200 \mathrm{ng} / \mathrm{mL}$ (Lemna minor growth inhibition with an $\mathrm{ED}_{50}$ of $0.5 \mu \mathrm{g} / \mathrm{mL}$ ) [139].

Three samples of the genus Symploca, all from Oahu, yielded five new peptides, malevamides A-E (267-271) [140-142] and symplostatin 3 (272) [143]. In an attempt to investigate Hawaiian samples of Symploca hynoides, cyanobacterial samples were collected from waters next to Ala Moana Beach Park. Later, it was 
discovered that the sample was primarily Symploca laete-viridis, which is morphologically similar to S. hynoides, and was contaminated with the species of interest. Re-collection, specifically of S. laete-viridis, yielded malevamides A-C (267-269) [140]. The second investigation of $S$. laete-viridis, from the same location, led to the isolation of malevamide $\mathrm{E}$ (271) [141], which was shown to have a dose-dependent inhibitory effect on the storeoperated calcium ion entry in thapsigargin-treated human embryonic kidney (HEK) cells at concentrations ranging from 2$45 \mu \mathrm{M}$. This was the first report of this type of depsipeptide as a modulator of calcium ion channels. In the paper, the authors also discuss a potential biosynthetic relationship between malevamide E (271 [○ Fig. 10]) and dolastatin 14 (273) amongst S. laete-viridis and its grazer, Dolabella auricularia. Malevamide D (270) was isolated from a sample of S. hydnoides collected off the south shore of Oahu [142].

Symplostatin 3 (272), a dolastatin 10 analogue, was isolated from a tumor selective extract of Symploca sp., VP452, collected from depths of 3-4m inside Kaneohe Bay, Oahu [143]. In bioassays aimed at assessing the in vitro cytotoxicity of $\mathbf{2 7 2}$, it was shown to have $\mathrm{IC}_{50} \mathrm{~S}$ ranging from $3.9-10.3 \mathrm{nM}$. Its mode of action, like that of dolastatin 10, was microtubule disruption.

Two articles by a San Diego-based group report on two new classes of natural products from a sample of Leptolyngbya crossbyana collected at a depth of $20 \mathrm{~m}$ from Honaunau, Big Island $[144,145]$. The first of these reports describes the crossbyanols A-D (274 [○ Fig. 10], 275-277), toxic penta-cyclic brominated polyphenyl ethers [144]. In a variety of bioassays, antimicrobial, cytotoxicity, voltage-gated sodium channel, and brine shrimp lethality, all compounds, except for crossbyanols C and D, demonstrated activity in at least one assay. The second report on the extract describes the honaucins A-C (278, 279, 280 [O Fig. 10]), potent inhibitors of inflammation and bacterial quorum sensing [145].

\section{Bacteria \\ $\nabla$}

A shallow-water sediment sample collected in 1996 from Wailupe Beach Park on the southeast shore of Oahu yielded the first Hawaiian bacterial strain, a Streptomyces sp., [Strain BD-26 T(20)] shown to contain interesting secondary metabolites, four new $\alpha$ pyrones, wailupemycins A-C (281-283), and 3-epi-5-deoxyenterocin (284 [○ Fig. 11]). Two of the isolates, wailupemycin A (281) and 284, exhibited selective antibacterial activity towards E. coli and S. aureus, respectively [146]. Streptomyces sp., strain BD-18 T(41), isolated from sediments collected at the mouth of Halawa Stream on the north shore of Oahu, whose $\mathrm{CCl}_{4}$ and $\mathrm{CHCl}_{3}$ solubles were shown to be antimicrobial, yielded a group of quinone-containing metabolites called halawanones A-D (285288), together with the known nanomycin $D$ [147]. The absolute configurations of the new compounds were determined employing both NMR and CD analyses. Strain BD21-2, Streptomyces sp., originated from a shallow-water sediment sample from Kailua Beach, Oahu. The EtOAc extract of the whole broth culture yielded the ester bonactin (289 [0 Fig. 11]), which showed weak to moderate broad spectrum antimicrobial activity towards a variety of microbes at the $100 \mu \mathrm{g}$ per disc (6 mm dia.) level; Bacillus megaterium (zone of inhibition [ZoI] $=8 \mathrm{~mm}$ ), Micrococcus luteus $(\mathrm{ZoI}=8 \mathrm{~mm})$, Klebsiella pneumoniea $(\mathrm{ZoI}=8.5 \mathrm{~mm})$, S. aureus $(\mathrm{ZoI}=7 \mathrm{~mm})$, Alicagenes faecalis $(\mathrm{ZoI}=10 \mathrm{~mm})$, E. coli

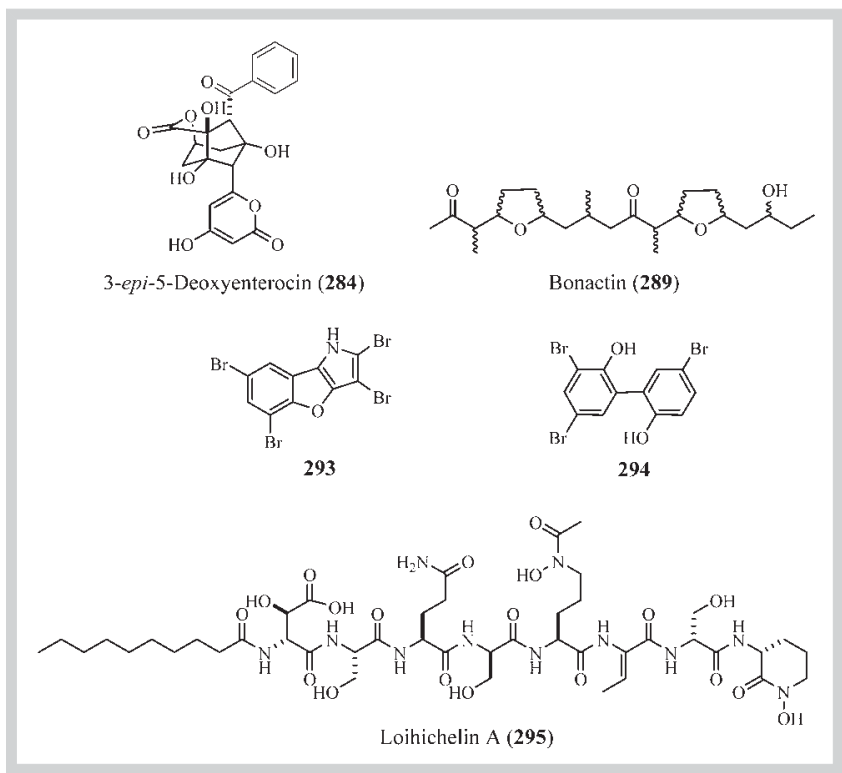

Fig. 11 Selected isolates from bacteria.

$(\mathrm{ZoI}=9 \mathrm{~mm})$, and Saccharomyces cerevisiae $(\mathrm{ZoI}=7.5 \mathrm{~mm})$; the first acyclic ester related to the nonactins to do so [148].

Nocardiopsis dassonvillei, actinomycete strain BH-609, purified from sediments collected along the high-tide line at Kahaka Beach Park, Kauai, was found to produce rare $\mathrm{N}$-glycosyl indoles, kahakamides A and B $(\mathbf{2 9 0}, \mathbf{2 9 1})$ related to neosidomycin [149]. This class of microbial compound contained only two other members prior to this report. Kahakamide A exhibited weak antimicrobial activity against $B$. subtilis.

From the surface of a nudibranch and the sponge Mycale armata recovered from waters off Oahu, pure cultures of Pseudoalteromonas rubra were established. The acetone diethyl ether $(2: 3)$ extract of the culture was shown to have significant cytotoxicity towards human ovarian adenocarcinoma cells (SKOV-3). A workup of this extract yielded the 2-substituted prodiginine, 2-( $p$ hydroxybenzyl)prodigiosin (292), that was active towards SKOV-3 cells ( $\mathrm{IC}_{50}$ of $\left.1.3 \mu \mathrm{M}\right)$ [150]. A second strain of Pseudoalteromonas (CMMED 290), also isolated from the surface of a nudibranch, this time collected in Kaneohe Bay, Oahu, produced two highly brominated compounds identified as 2,3,5,7-tetrabromobenzofuro[3,2-b]pyrrole (293) and 4,4',6-tribromo-2,2'biphenol (294). Both compounds exhibited antimicrobial activity against methicillin-resistant $S$. aureus $\left(\mathrm{IC}_{50}\right.$ of $1.93 \mu \mathrm{M}$ for 293 [O Fig. 11] and $2.19 \mu \mathrm{M}$ for 294 [O Fig. 11]) [151].

From a depth of $1714 \mathrm{~m}$ off of Loihi Seamount, $30 \mathrm{~km}$ south east of the Big Island, the basalt-weathering bacterium Halimonas sp. strain LOB-5 was isolated. Cultivation of the bacterium followed by purification employing solid-phase extraction (XAD-2 resin) and RP-HPLC yielded six new aphiphillic photoreactive siderophores, loihichelins A-F (295 [0 Fig. 11], 296-300) [152].

\section{Fungi}

$\nabla$

Interestingly, all of the reports concerning fungal isolates derived from Hawaiian waters are from research groups based on the mainland USA. The first of these appeared in 1989 and concerned Helicascus kanaloanus ordered from the American Type Culture 


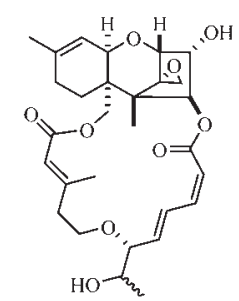

3-Hydroxyoroidin E (303)

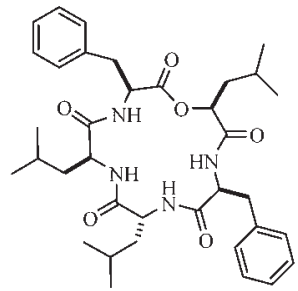

Zygosporamide (310)

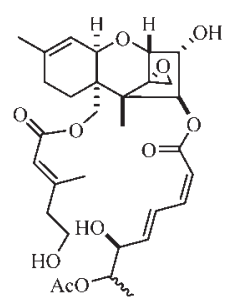

13'-Acetyltrichoverrin B (304)

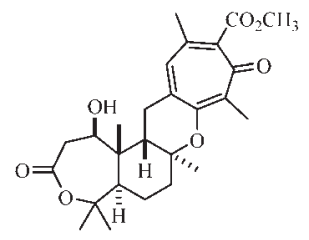

Tropolactone A (311)

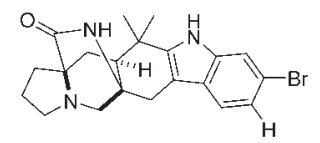

(+)-Malbrancheamide C (320)

Fig. 12 Selected isolates from fungi.

Collection (ATCC 18591), initially derived from a Hawaiian Mangrove. After cultivation in liquid media and extraction with EtOAc, the fungus was found to have produced two isomomeric $\delta$-lactones, helicasolides A and B $(\mathbf{3 0 1}, \mathbf{3 0 2})$ [153].

The next report concerning a marine fungus did not appear until 2003 and related to the extract made from Myrothecium verrucaria isolated from the sponge Spongia sp., collected from waters off of Maui. This investigation reported three new trichothecenes (303-305) and their cytotoxic properties. Activity against murine and human tumor cell lines was noted for 3-hydroxyoroidin $\mathrm{E}$

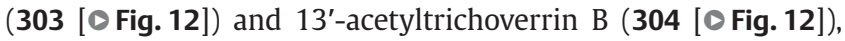
with miophytocen $\mathrm{C}$ (305) being found inactive in the same assays [154].

A strain of Exserohilum rostratum, originally associated with a cyanobacterial mat found off the coast of Lanai, yielded rostratins A-D (306-309). All rostratins, for which their absolute configurations are given, showed cytoxicity against human colon carcinoma (HCT-116) cells with $\mathrm{IC}_{50}$ values of $8.5,1.9,0.76$, and $16.5 \mu \mathrm{g} /$ $\mathrm{mL}$, respectively [155], suggesting a link between lipophilicity and activity.

The fermentation broth of fungal strain CNK458, identified as Zygosporium masonii isolated from an unidentified marine cyanobacterium collected off the coast of Maui, yielded zygosporamide (310 [๑ Fig. 12]). The molecule is a cyclic depsipeptide containing a D-amino acid residue that has significant activity in the National Cancer Institute's (NCI) 60 cell line panel with a median $\mathrm{GI}_{50}=9.1 \mu \mathrm{M}[156]$.

Aspergillus is the most documented genus of marine fungi studied from Hawaii. Organisms from this genus have produced tropolactones A-D (311 [ $\bullet$ Fig. 12], 312-314), azonazine (315), presclerotiotide $F(316)$, and sclerotiotide $F(317)$. The first report focused on strain CNK-371 isolated from an unidentified sponge collected at Manele Bay, Lanai, and described tropolactones A-D

(311-314), which showed cytotoxicity against human colon carcinoma (HCT-116) cells with $\mathrm{IC}_{50} \mathrm{~S}$ of $13.2,10.9$, and $13.9 \mu \mathrm{g} / \mathrm{mL}$ for tropolactone A, B, and C (311-313), respectively [157]. The strain of $A$. insulicola that produced azonazine (315), a unique hexacyclic dipeptide, was isolated from a marine sediment sample from Hawaii, with no further details given on the organism's origin [158]. Azonazine (315) proved to be inactive in applied assays [158]. A second study of $A$. insulicola, once again from a sediment collected in Hawaii, exact location not indicated, described the isolation of two new tripeptides, 316 and 317, both of which were devoid of activity in the applied test systems [159].

The final paper included in this review concerns a strain of Malbranchea graminicola isolated from an unidentified invertebrate collected by hand using self-contained underwater breathing apparatus (SCUBA) from Kona, Hawaii [160]. Investigation of the bioactive extract produced by the fungal culture led to the isolation of (-)-spiromalbramide (318) and (+)-isomalbrancheamide B (319), both apparently devoid of any bioactivity but of some chemical interest. The inspired part of this research was enrichment of the growth media of the fungus with bromine salts that caused the fungus to also produce the brominated compounds (+)-malbrancheamide C (320 [๑ Fig. 12]) and (+)-isomalbrancheamide $C$ (321) [160], hence revealing something more concerning the biosynthetic power of this microbe.

\section{Concluding Comments \\ $\nabla$}

Prior to starting this review we had only an inkling of an idea of the amount of research into Hawaiian marine organisms the groups led by Richard E. Moore and Paul J. Scheuer had undertaken. In many ways this is almost a review of their groups' pioneering research in the area of marine natural products from Hawaiian waters, hence the dedication at the start of the review. This research led to the discovery of many unique molecules being reported for the first time, palytoxin (195) [104] being a prime example. Another highlight would have to be the investigations undertaken with cyanobacteria that spawned a whole new area of research and led to the discovery of many new classes of molecules, including the lyngbyatoxins, pukeleimides, and the malevamides. In reality, much of the research undertaken in Hawaii formed the foundation of what we now know as modern marine natural products research.

Aside from the wonderful achievements highlighted above, our reading of the 160 publications that compose this review, plus many others read during the preparation of this review but not included, have left some other indelible impressions. The first of these is how little we actually still know about the hundreds of chemical entities discussed. Yes, we know a good deal about their chemical structures, their absolute configurations and the like, but for the vast majority, we know little or nothing about their roles in nature and, in a relative sense, our knowledge of their potential value to us as a species is restricted to a hand full of bioassays that mainly involve anticancer and antimicrobial studies. It is also astounding, given the amount of research funds, probably many millions of dollars, provided to the researchers cited in this review over the past 20-25 years by organizations like the US National Institutes of Health (NIH), that other organizations in Hawaii on islands other than Oahu, particularly in recent times, have not received similar funding or been encouraged to establish centers where the environment has been the subject of little or no scientific research investigation. We had also hoped to 
be citing at least one success story in terms of a compound that made it to the market place, instead we have hundreds of chemical entities that are apparently of no real use! The one exception to this seemingly harsh critique would have to be the antitumoral compound kahalalide $F$ (76) [44], which successfully reached phase II clinical trials for the treatment of patients with severe psoriasis. Unfortunately, the organization behind the development process, the Spanish-based pharmaceutical company PharmaMar, has apparently deprioritized further development of kahalalide F, probably due to a lack of significant efficacy and/ or funds.

Our last two major impressions relate to the general lack of careful documentation of species being investigated and the environments from which they were collected, as well as the continued totally random approach as to how samples are selected for study. In the early years, the 1960s and 1970s, research was being undertaken by groups of chemists who were breaking new ground and probably had limited exposure to biology and to the importance of accurate taxonomic identifications and all this encompasses. Nowadays, most reports have this information in some form, but still we see articles where this is not the case $[158,159]$, and some that do not even provide identification to the level of order [160]. Molecular taxonomic techniques can now be carried out routinely, and the importance of good taxonomy should be paramount in ensuring that natural products research continues to be relevant and reproducible. Finally, with the advent of the "omics"-age (e.g., genomics, proteomics), it is probably time for researchers to coordinate what they do to ensure approaches become systematized, clearly documented, and that all isolates are assessed in as many and varied bioassay systems as is possible. Also, it would make far more sense to make careful surveys of the biodiversity in specific areas around the Hawaiian Islands and collect samples representative of these so as to enable a meaningful picture of their ecology and bioactivity to be developed. This probably means an organization should become responsible for the creation of a Hawaiian natural products repository. This repository would be responsible for coordination, storage, and documentation of any natural products and natural product-related activities undertaken within the State of Hawaii; Hawaii is an absolutely unique and special place in our world and its natural resources need to be carefully and sustainably managed and used, or not used, for the benefit of everyone now and into the future.

\section{Supporting information}

Figs. $1 \mathrm{~S}-22 \mathrm{~S}$ and Table $1 \mathrm{~S}$ contain the structural formulae of compounds discussed in the review together with the taxonomy and collection location of the compounds' source organism, where known, as well as the main structural class to which the compounds belong, and either their trivial or semi-systemic name.

\section{Conflict of Interest}

$\nabla$

The authors declare no conflicts of interests.

\section{References}

1 Moore RE, Pettus jr. JA, Doty MS. Dictyopterene A, an odoriferous constituent from algae of the genus Dictyopteris. Tetrahedron Lett 1968; 9: $4787-4790$
2 Pettus jr. JA, Moore RE. Isolation and structure determination of an undeca-1,3,5,8-tetraene and dictyopterene B from algae of the genus Dictyopteris. Chem Commun 1970; 9: 1093-1094

3 Moore RE, Pettus jr. JA. The Isolation and structure determination of dictyopterenes $C^{\prime}$ and $D^{\prime}$ from Dictyopteris. Stereospecificity in the Cope rearrangement of dictyopterenes A and B. J Am Chem Soc 1971; 93: 3087-3088

4 Müller DG, Jaenicke L, Donike M, Akintobi T. Sex attractant in a brown alga: chemical structure. Science 1971; 171: 815-817

5 Roller P, Au K, Moore RE. Isolation of S-(3-oxoundecyl) thioacetate, bis(3-oxoundecyl) disulphide, (-)-3-hexyl-4,5-dithiacycloheptanone, and S-(trans-3-oxoundec-4-enyl) thioacetate from Dictyopteris. Chem Commun 1971; 10: 503-504

6 Moore RE. Bis-(3-oxoundecyl) polysulphides in Dictyopteris. Chem Commun 1971; 10: 1168-1169

7 Moore RE, Mistysyn J, Pettus jr. JA. (-)-Bis-(3-acetoxyundec-5-enyl) disulphide and $S$-(-)-3-acetoxyundec-5-enyl thioacetate, possible precursors to undeca-1,3,5-trienes in Dictyopteris. Chem Commun 1972; 6: 326-327

8 Moore RE, Yost G. Dihydrotropones from Dictyopteris. J Chem Soc Chem Commun 1973; 24: 937-938

9 Moore RE, Pettus jr. JA, Mistysyn J. Odoriferous $\mathrm{C}_{11}$ hydrocarbons from Hawaiian Dictyopteris. J Org Chem 1974; 39: 2201-2207

10 Sun HH, Waraszkiewicz SM, Erickson KL, Finer J, Clardy J. Dictyoxepin and dictyolene, two new diterpenes from the marine alga Dictyota acutiloba (Phaeophyta). J Am Chem Soc 1977; 99: 3516-3517

11 Hardt IH, Fenical W, Cronin G, Hay ME. Acutilols, potent herbivore feeding deterrents from the tropical brown alga, Dictyota acutiloba. Phytochemistry 1996; 43: 71-73

12 Finer J, Clardy J, Fenical W, Minale L, Riccio R, Battaile J, Kirkup M, Moore RE. Structures of dictyodial and dictyolactone, unusual marine diterpenoids. J Org Chem 1979; 44: 2044-2047

13 Kirkup MP, Moore RE. Identity of sanadaol with $\beta$-crenulal, a diterpene from the brown alga Dictyota crenulata. Phytochemistry 1983; 22: 2527-2529

14 Ishitsuka M, Kusumi T, Kakisawa H. Acetylsanadaol, a diterpene having a novel skeleton, from the brown alga, Pachydictyon coriaceum. Tetrahedron Lett 1982; 23: 3179-3180

15 Kirkup MP, Moore RE. Two minor diterpenes related to dictyodial A from the brown alga Dictyota crenulata. Phytochemistry 1983; 22: 2539-2541

16 Waraszkiewicz SM, Erickson KL. Halogenated sesquiterpenoids from the Hawaiian marine alga Laurencia nidifica: nidificene and nidifidiene. Tetrahedron Lett 1974; 23: 2003-2006

17 Waraszkiewicz SM, Erickson KL. Halogenated sesquiterpenoids from the Hawaiian marine alga Laurencia nidifica. II. Nidifidienol. Tetrahedron Lett 1975; 4: 281-284

18 Sun HH, Waraszkiewicz SM, Erickson KL. Sesquiterpenoid alcohols from the Hawaiian marine alga Laurencia nidifica. III. Tetrahedron Lett 1976; 8: 585-588

19 Waraszkiewicz SM, Erickson KL. Halogenated sesquiterpenoids from the Hawaiian marine alga Laurencia nidifica. IV. Nidifocene. Tetrahedron Lett 1976; 18: 1443-1444

20 Waraszkiewicz SM, Sun HH, Erickson KL. $\mathrm{C}_{15}$-Halogenated compounds from the Hawaiian marine alga Laurencia nidifica. V. The Maneonenes. Tetrahedron Lett 1976; 35: 3021-3024

21 Sun HH, Waraszkiewicz SM, Erickson KL. $C_{15}$-Halogenated compounds from the Hawaiian marine alga Laurencia nidifica. VI. The Isomaneonenes. Tetrahedron Lett 1976; 47: 4227-4230

22 Sun $H H$, Erickson KL. Sesquiterpenoids from the Hawaiian marine alga Laurencia nidifica. 7. (+)-Selin-4,7(11)-diene. J Org Chem 1978; 43: 1613-1614

23 Waraszkiewicz SM, Sun HH, Erickson KL. $\mathrm{C}_{15}$-Halogenated compounds from the Hawaiian marine alga Laurencia nidifica. Maneonenes and isomaneonenes. J Org Chem 1978; 43: 3194-3204

24 Cardellina JH, Moore RE. Sphingosine derivatives from red algae of the Ceramiales. Phytochemistry 1978; 17: 554-555

25 Kim IK, Brennan MR, Erickson KL. Lauroxolanes from the marine alga Laurencia majuscula. Tetrahedron Lett 1989; 30: 1757-1760

26 Brennan MR, Kim IK, Erickson KL. Kahukuenes, new diterpenoids from the marine alga Laurencia majuscula. J Nat Prod 1993; 56: 76-84

27 Juagdan EG, Kalidindi R, Scheuer P. Two new chamigranes from an Hawaiian red alga, Laurencia cartilaginea. Tetrahedron 1997; 53: 521-528 
28 Burreson BJ, Moore RE, Roller P. Haloforms in the essential oil of the alga Asparagopsis taxiformis (Rhodophyta). Tetrahedron Lett 1975; 16: 473-476

29 Burreson BJ, Moore RE, Roller PP. Volatile halogen compounds in the alga Asparagopsis taxiformis (Rhodophyta). J Agric Food Chem 1976; 24: 858-861

30 Woolard FX, Moore RE, Roller PP. Halogenated acetamides, but-3-en-2ols, and isopropanols from Asparagopsis taxiformis (Delile) Trev. Tetrahedron 1976; 32: 2843-2846

31 Woolard FX, Moore RE, Roller PP. Halogenated acetic and acrylic acids from the red alga Asparagopsis taxiformis. Phytochemistry 1979; 18: 617-620

32 Moore RE. Volatile compounds from marine algae. Acc Chem Res 1977; 10: $40-47$

33 Kirkup MP, Moore RE. Indole alkaloids from the marine red alga Martensia fragilis. Tetrahedron Lett 1983; 24: 2087-2090

34 Nagai H, Yasumoto T, Hokama Y. Aplysiatoxin and debromoaplysiatoxin as the causative agents of a red alga Gracilaria coronopifolia poisoning in Hawaii. Toxicon 1996; 37: 753-761

35 Nagai H, Yasumoto T, Hokama Y. Manauealides, some of the causative agents of a red alga Gracilaria coronopifolia poisoning in Hawaii. J Nat Prod 1997; 60: 925-928

36 Kato Y, Scheuer PJ. Aplysiatoxin and debromoaplysiatoxin, constituents of the marine mollusk Stylocheilus longicauda (Quoy and Gaimard, 1824). J Am Chem Soc 1974; 96: 2245-2246

37 Nagai H, Kan Y, Fujita T, Sakamoto B, Hokama Y. Manauealide C and anhydrodebromoaplysiatoxin, toxic constituents of the Hawaiian red alga, Gracilaria coronopifolia. Biosci Biotechnol Biochem 1998; 62: 1011-1013

38 Kan Y, Fujita T, Nagai H, Sakamoto B, Hokama Y. Malyngamides M and N from the Hawaiian red alga, Gracilaria coronopifolia. J Nat Prod 1998; 61: 152-155

39 Wang X, Liu X, Kono S, Wang G. The ecological perspective of microbial communities in two pairs of competitive Hawaiian native and invasive macroalgae. Microb Ecol 2013; 65: 361-370

40 Woolard FX, Burreson BJ, Moore RE. Isolation of (3S)-cis-octa-1,5-dien3-ol from Chondrococcus hornemanni (Rhodophyta). J Chem Soc Chem Commun 1975; 12: 486-487

41 Burreson BJ, Woolard FX, Moore RE. Chondrocole A and B, two halogenated dimethylhexahydrobenzenofurans from the red alga Chondrococcus hornemanni (Mertens) Schmitz. Tetrahedron Lett 1975; 26 2155-2158

42 Woolard FX, Moore RE, Van Engen D, Clardy J. The structure and absolute configuration of chondrocolactone, a halogenated monoterpene from the red alga Chondrococcus hornemanni, and a revised structure for chondrochole A. Tetrahedron Lett 1978; 27: 2367-2370

43 Horgen FD, Sakamoto B, Scheuer PJ. New triterpenoid sulphates from the red alga Tricleocarpa fragilis. J Nat Prod 2000; 63: 210-216

44 Hamann MT, Scheuer PJ. Kahalalide F: a bioactive depsipeptide from the sacoglossan mollusk Elysia rufescens and the green alga Bryopsis sp. J Am Chem Soc 1993; 115: 5825-5826

45 Hamann MT, Otto CS, Scheuer PJ. Kahalalides: bioactive peptides from a marine mollusk Elysia rufescens and its algal diet Bryopsis sp. J Org Chem 1996; 61: 6594-6600

46 Kan Y, Fujita T, Sakamoto B, Hokama Y, Nagai H. Kahalalide K: a new cyclic depsipeptide from the Hawaiian green alga Bryopsis sp. J Nat Prod 1999; 62: 1169-1172

47 Horgen FD, delos Santos DB, Goetz G, Sakamoto B, Kan Y, Nagai $H$ Scheuer PJ. A new depsipeptide from the sacoglossan mollusk Elysia ornata and the green alga Bryopsis species. J Nat Prod 2000; 63: 152-154

48 Dmitrenok A, Iwashita T, Nakajima $T$, Sakamoto B, Namikoshi $M$, Nagai $H$. New cyclic depsipeptides from the green alga Bryopsis species; application of a carboxypeptidase hydrolysis reaction to the structure determination. Tetrahedron 2006; 62: 1301-1308

49 Gao J, Caballero-George C, Wang B, Rao KV, Shilabin AG, Hamann MT. 5-OHKF and NorKA, depsipeptides from a Hawaiian collection of Bryopsis pennata: binding properties for NorKA to the human neuropeptide $Y_{1} Y_{1}$ receptor. J Nat Prod 2009; 72: 2172-2176

50 Carlos AA, Baillie BK, Kawachi M, Maruyama T. Phylogenetic position of Symbiodinium (Dinophyceae) isolates from tridacnids (Bivalvia), cardiids (Bivalvia), a sponge (Porifera), a soft coral (Anthozoa), and a freeliving strain. J Phycol 1999; 35: 1054-1062

51 Onodera $K$, Nakamura H, Oba Y, Ojika M. Zooxanthellamide A, a novel polyhydroxy metabolite from a marine dinoflagellate of Symbiodinium sp. Tetrahedron 2003; 59: 1067-1071
52 Onodera K, Nakamura H, Oba Y, Ojika M. Zooxanthellamide B, a novel large polyhydroxy metabolite from a marine dinoflagellate of Symbiodinium sp. Biosci Biotechnol Biochem 2004; 68: 955-958

53 Onodera K, Nakamura H, Oba Y, Ohizumi Y, Ojika M. Zooxanthellamide Cs: vasoconstrictive polyhydroxylated macrolides with the largest lactone ring size from a marine dinoflagellate of Symbiodinium sp. J Am Chem Soc 2005; 127: 10406-10411

54 Vijayavel K, Martinez JA. In vitro antioxidant and antimicrobial activities of two Hawaiian marine limu: Ulva fasciata (Chlorophyta) amd Gracilaria Salicornia (Rhodophyta). J Med Food 2010; 13: 1494-1499

55 Kelman D, Posner EK, McDermid KJ, Tabandera NK, Wright PR, Wright $A D$. Antioxidant activity of Hawaiian marine algae. Mar Drugs 2012; 10: 403-416

56 Hart GM, Ticktin T, Kelman D, Wright AD, Tabandera N. Contemporary gathering practice and antioxidant benefit of wild seaweeds in Hawai'i. Econ Bot 2014; 68: 30-43

57 Ravi BN, Perzanowski HP, Ross RA, Erdman TR, Scheuer PJ. Recent research in marine natural products: the puupehenones. Pure Appl Chem 1979; 51: 1893-1900

58 Luibrand RT, Erdman TR, Vollmer JJ, Scheuer PJ. Ilimaquinone, a sesquiterpenoid quinone from a marine sponge. Tetrahedron 1979; 35: 609612

59 Hagiwara K, Garcia Hernandez JE, Harper MK, Carroll A, Motti CA Awaya J, Nguyen HY, Wright AD. Puupehenol, a potent antioxidant antimicrobial meroterpenoid from a Hawaiian deep-water Dactylospongia sp. sponge. J Nat Prod 2015; 78: 325-329

60 Schulte G, Scheuer PJ, McConnell OJ. Upial, a sesquiterpenoid bicyclo [3.3.1]nonane aldehyde lactone from the marine sponge Dysidea fragilis. J Org Chem 1980; 45: 552-554

61 Schulte G, Scheuer PJ, McConnell OJ. Two furanosesquiterpene marine metabolites with antifeedant properties. Helv Chim Acta 1980; 63: 2159-2167

62 Nasu SS, Yeung BKS, Hamann MT, Scheuer PJ, Kelly-Borges M, Goins K Puupehenone-related metabolites from two Hawaiian sponges, Hyrtios spp. J Org Chem 1995; 60: 7290-7292

63 Sata N, Galario MA, Sitachitta N, Scheuer PJ, Kelly M. Poipuol, a new metabolite from a Hawaiian sponge of the genus Hyrtios. J Nat Prod 2005; 68: 262-263

64 Hagiwara KA, Harper-Ireland MK, Anklin C, Elyasberg M, Clark B, Wright $A D$. The use of DOSY in the structure elucidation of a Hawaiian deep-water sponge metabolite. Planta Med 2014; 80: PB14

65 Kalidindi RS, Yoshida WY, Palermo JA, Scheuer PJ. Pokepola ester: a phosphate diester from a Maui sponge. Tetrahedron Lett 1994; 35: 5579-5582

66 Erdman TR, Scheuer PJ. 28-Isofucosterol: major sterol of a marine sponge. Lloydia 1975; 38: 359-360

67 Theobald N, Shoolery JN, Djerassi C, Erdman TR, Scheuer PJ. 24-Ethyl$\Delta^{5,24(28), 28}$-cholestatrien-3 $\beta$-ol - a naturally occurring allenic marine sterol. J Am Chem Soc 1978; 100: 5574-5575

68 Corgiat JM, Scheuer PJ, Rios Steiner JL, Clardy J. Three pregnane-10,2carbolactones from a sponge, Strongylophora sp. Tetrahedron 1993 49: 1557-1562

69 Sata N, Abinsay H, Yoshida WY, Horgen FD, Sitachitta N, Kelly M, Scheuer PJ. Lehualides A-D, metabolites from a Hawaiian sponge of the genus Plakortis. J Nat Prod 2005; 68: 1400-1403

70 Carney JR, Yoshida WY, Scheuer PJ. Kiheisterones, new cytotoxic steroids from a Maui sponge. J Org Chem 1992; 57: 6637-6643

71 Carney JR, Scheuer PJ, Kelly-Borges $M$. Three unprecedented chloro steroids from the Maui sponge Strongylacidon sp.: Kiheisterones C, D, and E. J Org Chem 1993; 58: 3460-3462

72 Burreson BJ, Christopherson C, Scheuer PJ. Cooccurence of a terpenoid isocyanide-formamide pair in the marine sponge Halichondria sp. J Am Chem Soc 1975; 97: 201-202

73 Burreson BJ, Scheuer PJ. Isolation of a diterpenoid isonitrile from a marine sponge. J Chem Soc Chem Commun 1974; 24: 1035-1036

74 Burreson BJ, Christopherson C, Scheuer PJ. Cooccurence of two terpenoid isocyanide-formamide pairs in a marine sponge (Halichondria sp.). Tetrahedron 1975; 31: 2015-2018

75 Burreson BJ, Scheuer PJ, Finer J, Clardy J. 9-Isocyanopupukeanane, a marine invertebrate allomone with a new sesquiterpene skeleton. J Am Chem Soc 1975; 97: 4763-4764

76 Delseth C, Tolela L, Scheuer PJ, Wells RJ, Djerassi C. $5 \alpha$-24-Norcholestan$3 \beta$-ol and (24Z)-stigmasta-5,7,24(28)-trien-3 $\beta$-ol, two new marine sterols from the Pacific sponges Terpios zeteki and Dysidea herbacea. Helv Chim Acta 1979; 62: 101-109 
77 Gulavita NK, de Silva ED, Hagadone MR, Karuso P, Scheuer PJ. Nitrogenous bisabolene sesquiterpenes from marine invertebrates. J Org Chem 1986; 51: 5136-5139

78 Karuso P, Poiner A, Scheuer PJ. Isocyanoneopupukeanane, a new tricyclic sesquiterpene from a sponge. J Org Chem 1989; 54: 2095-2097

79 Hamann MT, Scheuer PJ. Cyanopuupehenol, an antiviral metabolite of a sponge of the order Verongida. Tetrahedron Lett 1991; 32: 56715672

80 Hamann MT, Scheuer PJ, Kelly-Borges M. Biogenetically diverse, bioactive constituents of a sponge, order Verongida: bromotyramines and sesquiterpene-shikimate derived metabolites. J Org Chem 1993; 58: 6565-6569

81 Lacy C, Scheuer PJ. New Moloka'iamine derivatives from an undescribed verongid sponge. J Nat Prod 2000; 63: 119-121

82 Ross SA, Weete JD, Schinazi RF, Wirtz SS, Tharnish P, Scheuer PJ, Hamann MT. Mololipids, a new series of anti-HIV bromotyraminederived compounds from a sponge of the order Verongida. J Nat Prod 2000; 63: 501-503

83 Jurek J, Yoshida WY, Scheuer PJ. Three new bromotyrosine-derived metabolites of the sponge Psammaplysilla purpurea. J Nat Prod 1993; 56: 1609-1612

84 Kato Y. Toxic constituents of the marine mollusk Stylocheilus longicauda [dissertation]. Manoa: University of Hawaii; 1973

85 Rose AF, Scheuer PJ, Springer JP, Clardy J. Stylocheilamide, an unusual constituent of the sea hare Stylocheilus longicauda. J Am Chem Soc 1978; 100: 7665-7670

86 Gallimore WA, Galario DL, Lacy C, Zhu Y, Scheuer PJ. Two complex proline esters from the sea hare Stylocheilus longicauda. J Nat Prod 2000; 63: 1022-1026

87 Gallimore WA, Scheuer PJ. Malyngamides O and P from the sea hare Stylocheilus longicauda. J Nat Prod 2000; 63: 1422-1424

88 Schulte GR, Chung MCH, Scheuer PJ. Two bicyclic $C_{15}$ enynes from the sea hare Aplysia oculifera. J Org Chem 1981; 46: 3870-3873

89 Hagadone MR, Burreson BJ, Scheuer PJ, Finer JS, Clardy J. Defense allomones of the nudibranch Phyllidia varicosa Lamarck 1801. Helv Chim Acta 1979; 62: 2484-2494

90 Terem B, Scheuer PJ. Scalaradial derivatives from the nudibranch Chromodoris youngbleuthi and the sponge Spongia oceania. Tetrahedron 1986; 42: 4409-4412

91 Okuda RK, Scheuer PJ, Hochlowski JE, Walker RP, Faulkner DJ. Sesquiterpenoid constituents of eight porostome nudibranchs. J Org Chem 1983; 48: 1866-1869

92 Ireland CM, Biskupiak JE, Hite GJ, Rapposch M, Scheuer PJ, Ruble JR. Ilikonapyrone esters, likely defense allomones of the mollusk Onchidium verruculatum. J Org Chem 1984; 49: 559-561

93 Roesener JA, Scheuer PJ. Ulapualide A and B, extraordinary antitumor macrolides from nudibranch egg masses. J Am Chem Soc 1986; 108 : 846-847

94 Guella G, Mancini I, Chiasera G, Pietra F. Sphinxolide, a 26-membered antitumoral macrolide isolated from an unidentified Pacific nudibranch. Helv Chim Acta 1989; 72: 237-246

95 Coval SJ, Scheuer PJ. An intriguing $\mathrm{C}_{16}$-alkadienone-substituted 2pyridine from a marine mollusk. J Org Chem 1985; 50: 3024-3025

96 Coval SJ, Schulte GR, Matsumoto GK, Roll DM, Scheuer PJ. Two polypropionate metabolites from the cephalaspidean mollusk Philinopsis speciosa. Tetrahedron Lett 1985; 26: 5359-5362

97 Reese MT, Gulavita NK, Nakao Y, Hamann MT, Yoshida WY, Coval SJ, Scheuer PJ. Kulolide: a cytotoxic depsipeptide from a cephalaspidean mollusk Philinopsis speciosa. J Am Chem Soc 1996; 118: 11081-11084

98 Nakao Y, Yoshida WY, Scheuer PJ. Pupukeamide, a linear tetrapeptide from a cephalaspidean mollusk Philinopsis speciosa. Tetrahedron Lett 1996; 37: 8993-8996

99 Nakao Y, Yoshida WY, Szabo CM, Baker BL, Scheuer PJ. More peptides and other diverse constituents of the marine mollusk Philinopsis speciosa. J Org Chem 1998; 63: 3272-3280

100 Kimura J, Takada Y, Inayoshi T, Nakao Y, Goetz G, Yoshida WY, Scheuer PJ. Kulokekakilide-1, a cytotoxic depsipeptide from the cephalaspidean mollusk Philinopsis speciosa. J Org Chem 2002; 67: 17601767

101 Nakao Y, Yoshida WY, Takada Y, Kimura J, Yang L, Mooberry SL, Scheuer PJ. Kulokekahilide-2, a cytotoxic depsipeptide from cephalaspidean mollusk Philinopsis speciosa. J Nat Prod 2004; 67: 1332-1340

102 Goetz G, Nakao Y, Scheuer PJ. Two acyclic kahalalides from the sacoglossan mollusk Elysia rufescens. J Nat Prod 1997; 60: 562-567
103 Rao KV, Na M, Cook JC, Peng J, Matsumoto R, Hamann MT. Kahalalides $\mathrm{V}-\mathrm{Y}$ isolated from a Hawaiian collection of the sacoglossan mollusk Elysia rufescens. J Nat Prod 2008; 71: 772-778

104 Moore RE, Scheuer PJ. Palytoxin: a new marine toxin from a coelenterate. Science 1971; 172: 495-498

105 Moore RE, Bartolini G. Structure of palytoxin. J Am Chem Soc 1981; 103: 2491-2494

106 Moore RE, Bartolini G, Barchi J, Bothner-By AA, Dadok J, Ford J. Absolute stereochemistry of palytoxin. J Am Chem Soc 1982; 104: 3776-3779

107 Quinn RJ, Kashiwagi M, Moore RE, Norton TR. Anticancer activity of zoanthids and the associated toxin, palytoxin, against Ehrlich ascites tumor and P-388 lymphocytic leukemia in mice. J Pharm Sci 1974; 63: 257-260

108 Ciminiello P, Dell'Aversano C, Dello Iacovo E, Forino M, Tartaglione L, Pelin M, Sosa S, Tubaro A, Chaloin O, Poli M, Bignami G. Stereoisomers of 42-hydroxy palytoxin from Hawaiian Palythoa toxica and P. tuberculosa: stereostructure elucidation, detection, and biological activities. J Nat Prod 2014; 77: 351-357

109 Missakian MG, Burreson BJ, Scheuer PJ. Pukalide, a furanocembranolide from the soft coral Sinularia abrupta. Tetrahedron 1975; 31: 2513-2515

110 Coll JC, Bowden BF, Heaton A, Scheuer PJ, Li MKW, Clardy J, Schukte GK, Finer-Moore J. Structures and possible functions of epoxypukalide and pukalide diterpenes associated with eggs of sinularian soft corals (Cnidaria, Anthozoa, Octocorallia, Alcyonacea, Alcyoniidae). J Chem Ecol 1989; 15: 1177-1191

111 Coval SJ, Scheuer PJ, Matsumoto GK, Clardy J. Two new xenicin diterpenoids from the octocoral Anthelia edmondsoni. Tetrahedron 1984; 40: 3823-3828

112 Baker BJ, Okuda RK, Yu PTK, Scheuer PJ. Punaglandins: halogenated antitumor eicosanoids from the octocoral Telesto riisei. J Am Chem Soc 1985; 107: 2977-2978

113 Schwartz RE, Yunker MB, Scheuer PJ, Ottersen T. Constituents of bathyal marine organisms: a new zoanthoxanthin from a coelenterate. Tetrahedron Lett 1978; 26: 2235-2238

114 Schwartz RE, Yunker MB, Scheuer PJ, Ottersen T. Pseudozoanthoxanthins from gold coral. Can J Chem 1979; 57: 1707-1711

115 Schwartz RE, Scheuer PJ, Zabel V, Watson WH. The coraxeniolides, constituents of pink coral, Corallium sp. Tetrahedron 1981; 37: 27252733

116 Bonini C, Kinnel RB, Li M, Scheuer PJ, Djerassi C. Minor and trace sterols in the marine invertebrates 38: isolation, structure elucidation and partial synthesis of papakusterol, a new biosynthetically unusual marine sterol with a cyclopropyl-containing side chain. Tetrahedron Lett 1983; 24: 277-280

117 Li MKW, Scheuer PJ. Halogenated blue pigments of a deep sea gorgonian. Tetrahedron Lett $1984 ; 25$ : 587-590

118 Anderson jr. AG, Nelson JA, Tazuma JJ. Azulene. III. Electrophilic substitution. J Am Chem Soc 1953; 75: 4980-4989

$119 \mathrm{Li}$ MKW, Scheuer PJ. N,N-Dimethylamino-3-guaiazulenylmethane from a deep sea gorgonian. Tetrahedron Lett 1984; 25: 4707-4708

$120 \mathrm{Li}$ MKW, Scheuer PJ. A guaianolide pigment from a deep sea gorgonian. Tetrahedron Lett 1984; 25: 2109-2110

121 Nagai H, Takuwa K, Nakao M, Sakamoto B, Crow GL, Nakajima T. Isolation and characterization of a novel protein toxin from the Hawaiian box jellyfish (sea wasp) Carybdea alata. Biochem Biophys Res Commun 2000; 275: 589-594

122 Chang CWJ, Moore RE, Scheuer PJ. The Structure of spinochrome M J Am Chem Soc 1964; 86: 2959-2961

123 Moore RE, Singh H, Scheuer PJ. Isolation of eleven new spinochromes from echinoids of the genus Echinothrix. J Am Chem Soc 1966; 31: 3645-3650

124 Moore RE, Singh H, Scheuer PJ. A Pyranonaphthazarin pigment from the sea urchin Echinothrix diadema. Tetrahedron Lett 1968; 43: 4581-4583

125 Higa T, Scheuer PJ. Constituents of the marine annelid Thelepus setosus. Tetrahedron 1975; 31: 2379-2381

126 Higa T, Okuda RK, Severns M, Scheuer PJ, He CH, Changfu X, Clardy J. Unprecedented constituents of a new species of acorn worm. Tetrahedron 1987; 43: 1063-1070

127 Moikeha SN, Chu GW, Berger LR. Dermatitis-producing alga Lyngbya majuscula Gomont in Hawaii. I. Isolation and chemical characterization of the toxic factor. J Phycol 1971; 7: 8-13

128 Engene N, Rottacker EC, Kaštovský J, Byrum T, Choi H, Ellisman MH, Komárek J, Gerwick WH. Moorea producens gen. nov., sp. nov. and 
Moorea bouillonii comb. nov., tropical marine cyanobacteria rich in bioactive secondary metabolites. Int J Syst Evol Microbiol 2012; 62: $1171-1178$

129 Cardellina II JH, Marner FJ, Moore RE. Seaweed dermatitis: structure of lyngbyatoxin A. Science 1979; 204: 193-195

130 Marner FJ, Moore RE, Hirotsu K, Clardy J. Majusculamides A and B, two epimeric lipodipeptides from Lyngbya majuscula Gormont. J Org Chem 1977; 42: 2815-2819

131 Marner FJ, Moore RE. (+)- $\alpha(S)$-Butyramido- $\gamma$-butyrolactone from Lyngbya majuscula. Phytochemistry 1978; 17: 553-554

132 Cardellina II JH, Dalietos D, Marner FJ, Mynderse JS, Moore RE. (-)-Trans-7(S)-methoxytetradec-4-enoic acid and related amides from the marine cyanophyte Lyngbya majuscula. Phytochemistry 1978; 17: 2091-2095

133 Cardellina II JH, Marner FJ, Moore RE. Malyngamide A, a novel chlorinated metabolite of the marine cyanophyte Lyngbya majuscula. J Am Chem Soc 1979; 101: 240-242

134 Cardellina II JH, Moore RE, Arnold EV, Clardy J. Structure and absolute configuration of Malyngolide, an antibiotic from the marine bluegreen alga Lyngbya majuscula Gormont. J Org Chem 1979; 44: 40394042

135 Simmons CJ, Marner FJ, Cardellina II JH, Moore RE, Seff K. Pukeleimide C, a novel pyrrolic compound from the marine cyanophyte Lyngbya majuscula. Tetrahedron Lett 1979; 22: 2003-2006

136 Cardellina II JH, Moore RE. The structures of pukeleimides A, B, D, E, F, and G. Tetrahedron Lett 1979; 22: 2007-2010

137 Aimi N, Odaka H, Sakai SI, Fujiki H, Suganuma M, Moore RE, Patterson GML. Lynbyatoxins B amd C, two new irritants from Lyngbya majuscula. J Nat Prod 1990; 53: 1593-1596

138 Kan Y, Sakamoto B, Fujita T, Nagai H. New malyngamides for the Hawaiian cyanobacterium Lyngbya majuscula. J Nat Prod 2000; 63: 1599-1602

139 Entzeroth M, Mead DJ, Patterson GML, Moore RE. A herbicidal fatty acid produced by Lyngbya aestuarii. Phytochemistry 1985; 24: 2875-2876

140 Horgen FD, Yoshida WY, Scheuer PJ. Malevamides A-C, new depsipeptides from the marine cyanobacterium Symploca laete-viridis. J Nat Prod 2000; 63: 461-467

141 Adams B, Porzgen P, Pittman E, Yoshida WY, Westenburg HE, Horgen FD. Isolation and structure determination of malevamide $E$, a dolastatin 14 analogue, from the marine cyanobacterium Symploca laete-viridis. J Nat Prod 2008; 71: 750-754

142 Horgen FD, Kazmierski EB, Westenburg HE, Yoshida WY, Scheuer PJ. Malevamide D: isolation and structure determination of an isodolastatin $\mathrm{H}$ analogue from the marine cyanobacterium Symploca hydnoides. J Nat Prod 2002; 65: 487-491

143 Luesch H, Yoshida WY, Moore RE, Paul VJ, Mooberry SL, Corbett TH. Symplostatin 3, a new dolastatin 10 analogue from the marine cyanobacterium Symploca sp. VP452. J Nat Prod 2002; 65: 16-20

144 Choi H, Engene N, Smith JE, Preskitt LB, Gerwick WH. Crossbyanols A-D, toxic brominated polyphenol ethers from the Hawai'ian bloom-forming cyanobacterium Leptolyngbya crossbyana. J Nat Prod 2010; 73: 517-522

145 Choi H, Mascuch SJ, Villa FA, Byrum T, Teasdale ME, Smith JE, Preskitt LB, Rowley DC, Gerwick L, Gerwick WH. Honaucins A-C, potent inhibitors of inflammation and bacterial quorum sensing: synthetic derivatives and structure-activity relationships. Chem Biol 2012; 19: 589-598

146 Sitachitta N, Gadepalli M, Davidson BS. New $\alpha$-pyrone-containing metabolites from a marine-derived actinomycete. Tetrahedron 1996; 52: 8073-8080

147 Ford PW, Gadepalli M, Davidson BS. Halawanones A-D, new polycyclic quinones from a marine-derived streptomycete. J Nat Prod 1998; 61: $1232-1236$

148 Schumacher RW, Talmage SC, Miller SA, Sarris KE, Davidson BS, Goldberg A. Isolation and structure determination of an antimicrobial ester from a marine sediment-derived bacterium. J Nat Prod 2003; 66: 1291-1293

149 Schumacher RW, Harrigan BL, Davidson BS. Kahakamides A and B, new neosidomycin metabolites from a marine-derived actinomycete. Tetrahedron Lett 2001; 42: 5133-5135

150 Feher D, Barlow RS, Lorenzo PS, Hemscheidt TK. A 2-Substituted prodiginine, 2-( $p$-hydroxybenzyl)prodigiosin, from Pseudoalteromonas rubra. J Nat Prod 2008; 71: 1970-1972

151 Feher D, Barlow R, McAtee J, Hemscheidt TK. Highly brominated antimicrobial metabolites from a marine Pseudoalteromonas sp. J Nat Prod 2010; 73: 1963-1966

152 Homann VV, Sandy M, Tincu JA, Templeton AS, Tebo BM, Butler A. Loihichelins A-F, a suite of amphiphilic siderophores produced by the marine bacterium Halomonas LOB-5. J Nat Prod 2009; 72: 884888

153 Poch GK, Gloer JB. Helicasolides A and B: new lactones from the marine fungus Helicascus kanaloanus. J Nat Prod 1989; 52: 257-260

154 Amagata T, Rath C, Rigot JF, Tarlov N, Tenney K, Valeriote FA, Crews P. Structures and cytotoxic properties of trichoverroids and their macrolide analogues produced by saltwater culture of Myrothecium verrucaria. J Med Chem 2003; 46: 4342-4350

155 Tan RX, Jensen PR, Williams PG, Fenical W. Isolation and structure assignments of rostratins $A-D$, cytotoxic disulphides produced by the marine-derived fungus Exserohilum rostratum. J Nat Prod 2004 67: $1374-1382$

156 Oh DC, Jensen PR, Fenical W. Zygosporamide, a cytotoxic cyclic depsipeptide from the marine-derived fungus Zygosporium masonii. Tetrahedron Lett 2006; 47: 8625-8628

157 Cueto M, MacMillan JB, Jensen PR, Fenical W. Tropolactones A-D, four meroterpenoids from a marine-derived fungus of the genus Aspergillus. Phytochemistry 2006; 67: 1826-1831

$158 \mathrm{Wu}$ QX, Crews MS, Draskovic M, Sohn J, Johnson TA, Tenney K, Valeriote FA, Yao XJ, Bjeldanes LF, Crews P. Azonazine, a novel dipeptide from a Hawaiian marine sediment-derived fungus, Aspergillus insucola. Org Lett 2010; 12: 4458-4461

159 Wu QX, Draskovic M, Crews MS, Tenney K, Valeriote FA, Yao XJ, Crews $P$. Unraveling the numerous biosynthetic products of the marine sediment-derived fungus, Aspergillus insucola. Phytochem Lett 2012; 5 : $114-117$

160 Watts KR, Loveridge ST, Tenney K, Media J, Valeriote FA, Crews P. Utilizing DART mass spectrometry to pinpoint halogenated metabolites from a marine invertebrate-derived fungus. J Org Chem 2011; 76 : 6201-6208 